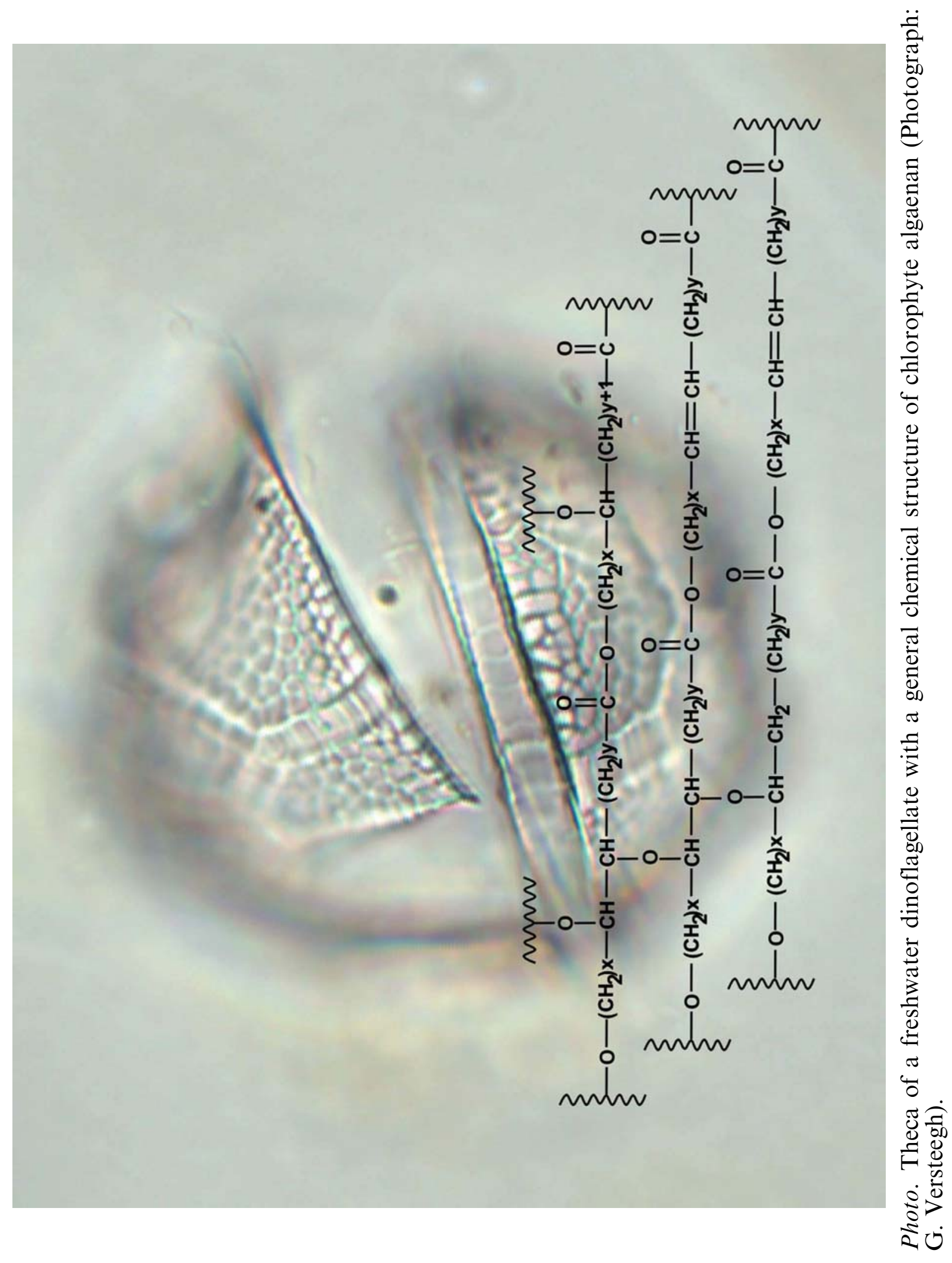




\title{
Biomacromolecules of algae and plants and their fossil analogues
}

\author{
Jan W. de Leeuw ${ }^{1,2,3, *}$, Gerard J. M. Versteegh ${ }^{1,2,4}$ and Pim F. van Bergen ${ }^{5}$ \\ ${ }^{1}$ Royal Netherlands Institute for Sea Research, 1797 SZ 't Horntje, Texel, The Netherlands; ${ }^{2}$ Organic \\ Geochemistry, Faculty of Geosciences, Utrecht University, Budapestlaan 4, 3584CD, Utrecht, The \\ Netherlands; ${ }^{3}$ Palaeoecology, Faculty of Biology, Budapestlaan 4, 3584CD, Utrecht, The Netherlands; \\ ${ }^{4}$ Hanse Wissenschaftskolleg, Lehmkuhlenbusch 4, 27753, Delmenhorst, Germany; ${ }^{5}$ Shell Global Solutions \\ International, Badhuisweg 3, 1031 CM, Amsterdam, The Netherlands; *Author for correspondence (e-mail: \\ deleeuw@nioz.nl)
}

Received 1 September 2004; accepted in revised form 15 December 2004

Key words: Algaenan, Biomacromolecule, Diagenesis, Fossil, Recent, Sporopollenin

\begin{abstract}
A review of our current understanding of resistant biomacromolecules derived from present and past algae and higher plants is presented. Insight in the nature of recent and fossil macromolecules is strongly hampered by the difficulties in obtaining the material in pure and unaltered form. For the extant material, avoiding artificial condensation and structural alteration as a result of chemical isolation and purification of biomacromolecules requires constant attention. To date, several types of sporopollenin seem to occur. One type is characterised by oxygenated aromatic building blocks, in particular $p$-coumaric acid and ferrulic acid. The other type is thought to consist predominantly of an aliphatic biopolymer. In this review it is concluded that extant sporopollenin consists of the aromatic type, whereas the aliphatic component of fossil sporopollenin is due to early-diagenetic oxidative polymerization of unsaturated lipids. The cuticles of most higher plants contain the aliphatic biopolyester cutin. Additionally, cuticles of drought-adapted, mostly CAM plants, seem to contain the non-hydrolysable aliphatic biopolymer cutan. Only a very few algae are able to biosynthesize resistant, (fossilisable) cell walls: some Chlorophyta, Eustigmatophyta and Prasinophyta produce the aliphatic biopolymer algaenan. Some Dinophyta are also capable of producing algaenan cell walls. Additionally, some taxa produce highly resistant cyst-walls with a high proportion of aromatic moieties. For the morphologically well-preserved fossil material, contamination by organic particles other than the target taxon is hard to eliminate and can contribute to either the aliphatic or aromatic signal. Furthermore, post-mortem migration of aliphatic moieties into, and their condensation onto the macromolecule might occur, e.g. by oxidative polymerization. These phenomena hamper the evaluation of the aliphatic signature of fossil plant material and may for example explain the preservation of initially cutin-based cuticles or non-algaenan containing algae. The extent to which migration and in situ formation of aromatic moieties plays a role in modifying resistant algal macromolecules, notably under elevated temperature and/or pressure conditions, still remains an open question.
\end{abstract}

\section{Introduction}

To extend our understanding of present-day and future natural and anthropogenic climate change, detailed reconstructions of palaeo-environments (with limited or no human factor) and their changes through geological time are crucial. Such reconstructions may be based on instrumental, 
historical and so-called proxy data. Instrumental data are reliable, but are very limited in time, i.e. at the most 200 years BP. Historical data can be retrieved for millennia but become less reliable with time. Ancient reconstructions rely on proxy data from dated sediment cores, ice cores or fossils. 'Direct' proxies concern environmental entities which are measured as such in the geological record, e.g. measurements of $p \mathrm{CO}_{2}$ in air bubbles in ice cores. 'Indirect' proxies are entities analysed from sediments, ice cores and fossils formed during the time in question and transfer functions enable these entities to be used to reconstruct past environment and climate. Indirect biomarker proxies should be stable, difficult to degrade or mineralise and have locked-up environmental parameters such as temperature, salinity, humidity, redox potential, etc. Even in the case of partial degradation or mineralisation of biomarkers, ratios of biomarkers may serve as indirect proxies provided that the rate of partial diagenesis of the biomarkers making up the ratio is the same (e.g. Müller et al. 1998; Versteegh et al. 2000; Schouten et al. 2002).

To evaluate existing proxies or to develop new proxies based on organic compounds derived from algae and higher plants, a much better understanding of the origin, the structure, the function and diagenesis of specific low- and high-molecularweight organic matter is crucial. This chapter therefore focuses on several aspects of molecular structures of resistant biopolymers in algae and higher plants and their fossilised counterparts and can be considered as an extension and up-date of a recent review by van Bergen et al. (2004).

\section{Sporopollenin}

Studies concerning the chemical structure of extant and fossilised spore- and pollen-walls have a long history. These studies have been reviewed recently by van Bergen et al. $(1995,2004)$ and by de Leeuw and Largeau (1993). Based on these reviews and the references cited therein it has been concluded that several types of extant sporopollenins of a variety of ferns, conifers and angiosperms may occur. Although no systematic chemical studies are known regarding relations of these structures with haploid or diploid sporophytes, or about different spore/pollen-wall layers and the different ways different plant groups produce spores and pollen.

One type is characterised by oxygenated aromatic building blocks, in particular $p$-coumaric and ferulic acid. The other type is thought to consist predominantly of an aliphatic biopolymer of unknown structure (e.g. Guilford et al. 1988; Hayatsu et al. 1988; Domínguez et al. 1999). Whether or not two or even more different types of sporopollenins exist - and the extent to which both types may occur in the same pollen-grain or spore, in separate layers or mixed - is not clear and difficult to determine because a multitude of different, incomparable methods have been used to separate the spore- or pollen-walls from the contents of the spores and pollen consisting of lipids, proteins, polysaccharides, etc. In virtually all cases this separation has been performed chemically, sometimes under very harsh conditions. The chemical methods applied may alter the structure of sporopollenin, may remove specific parts of the sporopollenin or may not be complete in removing non-sporopollenin constituents. This problem is approached by assuming that during burial and diagenesis sporopollenin behaves conservatively and that other non-sporopollenin constituents are selectively degraded and mineralised. This assumption is justified on the basis of the presence of perfectly morphologically preserved spore- and pollen-walls in sediments without microscopically recognisable remains of the contents of spores and pollen. In other words it was assumed that diagenetic processes represent the best (geo)chemical pathway to purify sporopollenin.

However it must be noted that the diagenetic 'purification' of sporopollenin probably depends on the preservation conditions. Yule et al. (2000) demonstrated through micro-FTIR that the spores of Lycopodium clavatum go through various phases of chemical degradation characterised by an initial relative increase in aliphatics followed by a FTIR signal more dominated by an aromatic signal. Especially oxidative conditions might affect the final chemistry of the remaining material as illustrated by Gabarayeva et al. (2003) who demonstrated that by successive chemical treatments starting with a relatively mild glacial acetic acid followed by oxidative potassium permanganate degradation isolates the exine of pollen but progressively erodes it specifically with the duration of the treatment. Though the permanganate 
conditions may not have an equivalent under 'natural' conditions it illustrates that the sporopollenins investigated by Gabarayeva et al. (2003) can be regarded as inhomogeneous on a molecular level probably with respect to polymerisation grade of the monomeric components. So the degree of diagenetic purification and degradation, together with the wide variety of analytical techniques and samples analysed over time results in a extremely blurred insight into the actual chemistry of sporopollenin. Furthermore, there is no elaborate information on the effect of climatic conditions on the chemistry of sporopollenin, making it difficult to interpret the chemical data obtained from fossil materials solely.

To date, however, virtually all fossilised sporeand pollen-walls analysed consist of both aromatic and highly aliphatic moieties as revealed by pyrolytic and spectroscopic data (e.g. Schenck et al. 1981; van Bergen et al. 1993, 1995, 2004, subm.), even if their recent counterparts are almost exclusively of the aromatic type. To illustrate this phenomenon the pyrolysates of extant and fossil Salvinia megaspores are compared (van Bergen et al. 1993; Figure 1). In this particular example the extant megaspore material, exine and perispore, was dissected from mature plants and extracted extensively with organic solvents to remove low-molecular-weight organic matter, thus representing one of the very few extant spore wall isolations without extensive chemical treatments.

The gas chromatogram of the pyrolysate of the extant spore wall consists almost exclusively of peaks representing aromatic compounds that can be produced from a polymeric form of $p$-coumaric acid (see hereafter). Aliphatic compounds, i.e. $\mathrm{C}_{16}$ and $\mathrm{C}_{18}$ fatty acids (FAs), are present as minor compounds in the pyrolysate. It is not clear whether these aliphatic compounds originate from sporopollenin or represent membrane or other lipids associated with the material. In sharp contrast the pyrolysate of the fossil megaspore

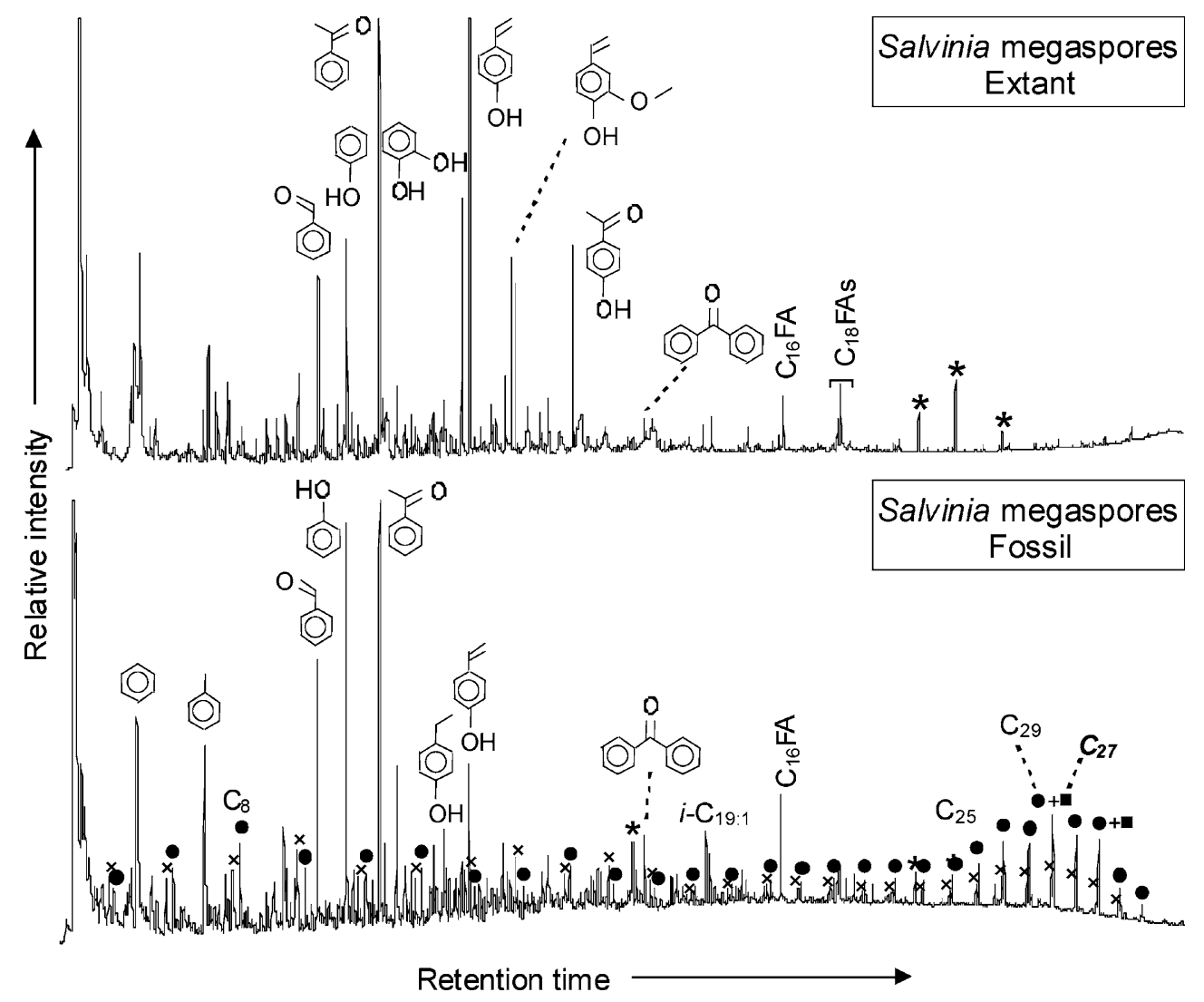

Figure 1. Comparison of pyrolysates of extant and fossil Salvinia megaspores. $\mathrm{x}=n$-alk-1-enes, $*=$ contaminants (van Bergen et al. 1993). 
wall material yields a strong aliphatic signal as indicated by the homologous series of alkane/alkene doublets. A number of aromatic compounds similar to those recognised in the modern material are still present, in particular, acetophenone and 4-vinylphenol; the latter most probably is a pyrolysis product of $p$-coumaric acid.

To explain the clear and sometimes dominant occurrence of aliphatic constituents in these and other fossilised spore- and pollen-walls it has been assumed that the corresponding or related extant sporopollenins do contain a (very) small portion of aliphatic building blocks that are selectively preserved at the cost of the aromatic constituents, i.e. cinnamic acids such as $p$-coumaric and ferulic acid, during burial and diagenesis. However, it cannot be excluded that the aliphatic constituent represents an aliphatic geopolymer produced during burial and diagenesis from low-molecular-weight lipids such as plant waxes (cf. Collinson et al. 1998) consisting of saturated and unsaturated hydrocarbons, alcohols FAs or from membrane lipids, consisting of saturated and unsaturated FAs, or, most likely, from unsaturated lipids present in the original spores and pollen that have become attached to the original sporopollenin serving as a matrix through oxidative cross linking.

Strong circumstantial evidence of such an oxidative cross linking of low-molecular-weight lipids is presented by a recent study of Versteegh et al. (2004) through a very detailed analysis of a dominantly present aliphatic constituent in morphologically very well preserved fossil algae (dinoflagellates). These algae did not contain a microscopically recognisable cell wall, thus indicating that the aliphatic constituent could not represent algaenan, a biopolymer present in several algae (van Bergen et al. 2004 for a review) and this paper. Based on extensive and detailed microscopical, chemical and spectroscopical analyses of these preserved dinoflagellates, Versteegh et al. (2004) had to conclude that a 'post-mortem polymerisation' of FA moieties from phospholipids, glycolipids or glycerol esters originally present in the cytoplasm by means of cross linking through ether bonds had taken place. Analogous to the migration and condensation of aliphatic lipids described for cavities in coals (Zhang et al. 1993), migration of additional aliphatic moieties from the surrounding environment taking part in the polymerisation process forming the preserved dinoflagellates can not be excluded either. Further detailed evidence for this oxidative cross-linking during diagenesis is described by Kuypers et al. (2002), in a study of Cretaceous black shales. In that study it has been evidenced that a substantial part of the kerogen of these shales consists of ether-linked isoprenoids derived from archaeal membranes as indicated by advanced pyrolysis GC-MS studies in combination with chemical degradation using $\mathrm{RuO}_{4}$ oxidation. Furthermore, post-mortem formation of an ether cross-linked aliphatic biopolymer been observed in fossil arthropod cuticles (Briggs et al. 1995; Stankiewicz et al. 2000). In this case, the original chitin-based cuticles had been preserved very well morphologically, whereas the chitin was completely replaced by a full aliphatic non-hyrolysable geopolymer. Moreover, there are other indications that this oxidative lipid polymerisation during burial and diagenesis has been underestimated. For example, the oxidative polymerisation of triacylglycerols is a long known process, well known from the drying of linseed oil-based paints triggered by the autooxidation of unsaturated FAs (e.g. Blom, 1936; Fjällström et al. 2002), causes problems in vegetable oil storage and their use for diesel fuel engines (e.g. Srivastava and Prasad 2000) and is easily induced in the laboratory by keeping vegetable oil in sunlight (Versteegh et al. 2004). Finally, the absence of cutan in living Ginkgo suggests that fossil Ginkgo cuticles originate from oxidative cross linking of the less resistant, saponifiable organic entities originally suggested to be cutin (Mösle et al. 1997), later believed to be derived from cuticular lipids (Collinson et al. 1998).

The above clearly illustrates that the assumption that well-preserved fossil spore- and pollen-walls are highly representative for the chemistry of extant sporopollenin may be invalid, although further studies including FTIR and ${ }^{13} \mathrm{C}$ NMR spectroscopy are required to substantiate this. During burial and diagenesis the original biopolymer can change and/or newly generated geopolymers may be generated and may become closely associated with the original biopolymer or may even completely replace the original biopolymer without a change in morphology. Thus, these types of processes also indicate that chemical treatments of extant spore- and pollen-walls to separate sporopollenin from the cytoplasm constituents are rather problematic and have to be kept in mind 
when interpreting results of sporopollenin studies based on the chemical separation of sporopollenin.

In a very recent study (Boom 2004) isolated megaspore walls of Isoetes killipi C. Morton were treated relatively mildly by sulphuric acid to remove proteins and polysaccharides and after extractions to remove low-molecular-weight lipids. The resistant material obtained was analysed using a series of complementary analysis methods such as Direct Temperature-resolved Mass Spectrometry (DTMS), Curie-point pyrolysis-GC/MS (Py-GC/MS) and Fourier Transform-IR (FTIR). The data showed that the sporopollenin of these spores consists of polymerised $p$-coumaric acid because the analysis data were very similar to those of a synthetic $p$-coumaric acid-based dehydrogenation polymer (DHP) (Figure 2). The only difference between the synthetic polymer and the sporopollenin was explained by a small additional contribution of ferulic acid moieties in the Isoetes spore walls. The chemical treatment used in this particular case had not produced an aliphatic polymer.

Based on this and earlier results (e.g. Wehling et al. 1989; Mulder et al. 1992) and on reinspection of other literature data concerning the oxidised aromatic type sporopollenin it may be concluded that sporopollenin consists of DHP type polymers based on $p$-coumaric acid and some ferulic acid, predominantly through ether linkages at the alpha, beta and $\mathrm{C}_{4}$ carbon atoms and that the aliphatic constituent in fossilised spore- and pollen-walls is not part of the original
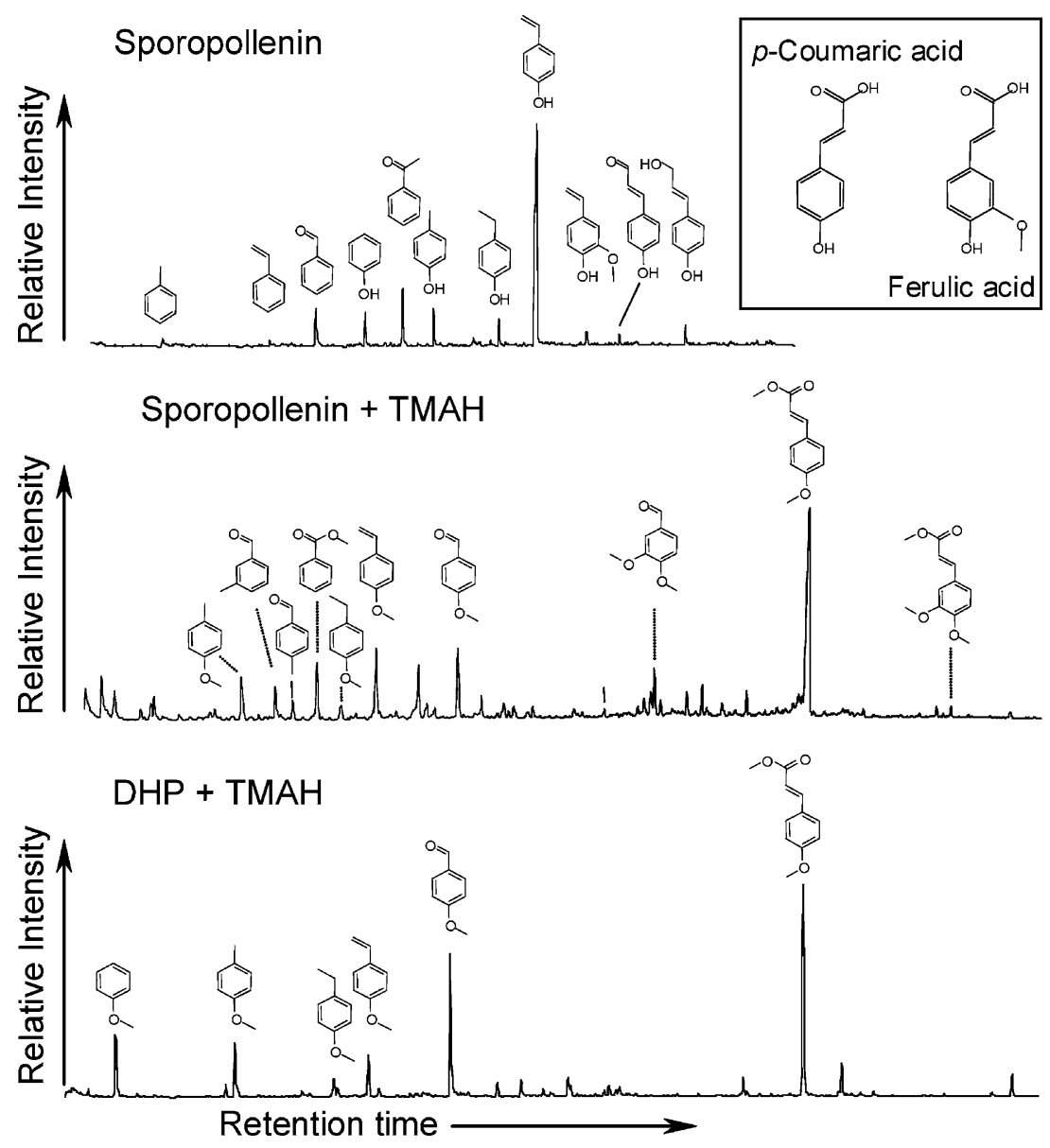

Figure 2. a. Pyrolysate of Isoetes killipii megaspore walls. b. Pyrolysate of Isoetes killipii megaspore walls with tetramethylammonium hydroxide (TMAH) coating. Upon thermolysis the TMAH methylates the oxygen radicals preventing secondary reactions of the pyrolysis products. c. Pyrolysate of a synthetic, $p$-coumaric acid-based, dehydrogenation polymer (DHP). The similarity of this pyrolysate with that of the Isoetes killipii megaspore walls confirms the high proportion of $p$-coumaric acid in the latter. (Adapted from (Boom 2004). 
sporopollenin structure. Its highly variable presence and signature in many fossil spore- and pollen-walls may be due to the co-occurrence of the aromatic constituent representing the original sporopollenin, i.e. polymeric $p$-coumaric acid present as such or transformed during diagenesis, and an allochtonously-derived aliphatic component, i.e. a diagenetically produced geopolymer as indicated above. Depending on its availability, this aliphatic component may be derived from the entity itself and/or, from the outside, i.e. directly from the sediment.

This hypothesis implies that the relative proportion of $p$-coumaric acid or, more generally, cinnamic acids or their diagenetic counterparts present in fossil spore- and pollen-walls can not be used straightforwardly as a proxy for UV-B exposure as has been suggested earlier (Rozema et al. 2001, 2002). It is, however, interesting to investigate whether ratios of cinnamic acids or even the degree of esterified $p$-coumaric acid over ether-bound $p$-coumaric acid, can be used as UV-B proxies.

\section{Cutin and cutan}

The dominant, sometimes exclusive, presence of a non-hydrolysable aliphatic polymer in well-preserved and morphologically recognisable fossil cuticles led to the assumption that such a polymer occurs as a biopolymer labelled cutan, in a variety of extant plant cuticles (Figure 3; de Leeuw and Largeau 1993; van Bergen et al. 2004). This cutan should not be confused with cutin, a long and well-known biopolyester present in almost every plant cuticle (see hereafter). In several cases, however, the non-hydrolysable aliphatic polymer thought to represent the preserved and selectively preserved biopolymer cutan was only present in the fossil cuticles and not in the extant counterparts consisting of cutin only (Mösle et al. 1997; Collinson et al. 1998). As is the problem with sporopollenin (see above) the genesis of an aliphatic geopolymer replacing the cutin in the original cuticles has to be assumed (cf. Tegelaar et al. 1991; Collinson et al. 1998). In this particular case the most likely candidates to be transferred diagenetically into an aliphatic polymer are cutin (cf. Tegelaar et al. 1991) and/ or leaf waxes (cf. Collinson et al. 1998), since these aliphatic constituents are part of the cuticle or very closely associated with it, respectively. Pyrolysates of fossil cuticles consist mostly of homologous series of alkanes and alkenes with carbon chain lengths up to $\mathrm{C}_{30}$ to $\mathrm{C}_{35}$ (Figure 3) indicating that leaf waxes are the preferred

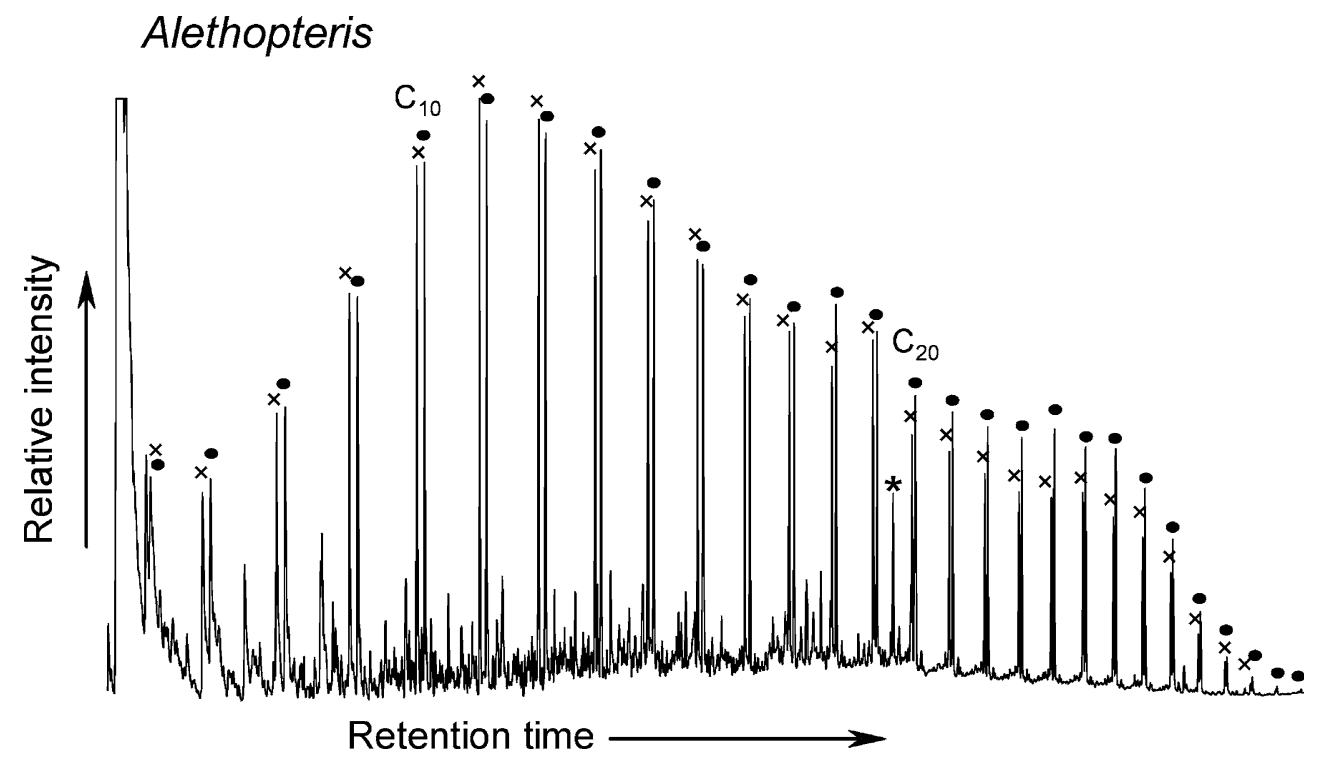

Figure 3. Pyrolysate of Alethopteris lesquereuxi pinnule cuticle (Carboniferous). $\mathrm{x}=n$-alk-1-enes, (after Collinson et al. 1994). 
candidates since the FA building blocks of cutin are $\mathrm{C}_{16}$ and $\mathrm{C}_{18}$ saturated and unsaturated FAs (e.g. Holloway 1982).

Once again, the problem is whether or not there exists a non-hydrolysable biopolymer cutan next to the biopolyester cutin in extant cuticles, also taking into consideration that chemical treatments performed to purify cutan from the cuticle matrix may lead to artefacts similarly to those mentioned above for sporopollenin. Until recently, rigourous studies of extant cuticles showed that the biopolymer cutan is indeed present in the cuticle of Agave americana and Clivia miniata, but that the presence of cutan previously reported in a number of other plant cuticles could not be confirmed (Collinson et al. 1998). Very recently however, cutan has been reported as a significant component of the cuticles in drought-adapted, mostly CAM plants (Boom 2004). Although these cutans were isolated chemically by extractions and acid- and base treatments no artificial aliphatic polymer was produced since other, non-drought-adapted plant cuticles treated identically, thus serving as blanks, yielded no cutan. Boom et al. (2005) speculate that the presence of cutan in the thick cuticles of these CAM plants serves as a physiological and chemical adaptation to survive drought conditions. Further studies have to show whether the presence of cutan in fossil plants cuticles can be used as indicators, i.e. proxies, for drought. These data imply that the selectively preserved biopolymer cutan must be discriminated from the diagenetically produced aliphatic geopolymer in fossil cuticles.

Several studies have indicated the presence of cinnamic acids, in particular $p$-coumaric and ferulic acid, as constituents of isolated extant and fossil cuticles from leaves and seeds from several plants (e.g. Deshmukh et al. 1964; Kolattukudy 1981; Holloway 1982; van Bergen 1994; McKinney et al. 1996; Collinson and van Bergen 2004; van Bergen et al. 2004). These aromatic components may be derived from the cell wall of the epidermis directly underlying the cuticle. Further studies have to reveal if these aromatic components play a role in the shielding of UV-B and if they can serve as proxies of UV-B irradiation in the palaeo-environment using well-dated fossilised cuticles (Rozema et al. 2001, 2002).

\section{Resistant algal biomacromolecules}

Micro-algae are diverse and abundant in aquatic environments. Most of them have no, or only very limited preservation potential. Nevertheless, a diverse and rich micro-algal fossil record of aquatic palynomorphs exists. This record is an important source of information for solving stratigraphic, palaeoenvironmental (e.g., palaeoclimatological) and evolutionary questions. For this purpose, almost solely the morphological characteristics of the fossils have been used, whereas their potential at the molecular level hardly has been exploited. As a result our knowledge of the structure, chemical diversity, function and diagenesis of the cell walls of algae is still very fragmentary. Improving this knowledge addresses directly the formation, transport and degradation of organic matter, which is central to our understanding of biogeochemical cycles, the formation of petroleum, gas and coal and the history of life and its environment. Below, an overview will be given on our current knowledge of cell wall biomacromolecules from micro-algae and their fossil geomacromolecular analogues.

\section{Cell walls from extant micro-algae}

Only the biomacromolecules of cell walls that are considered to fossilise will be discussed here. For cell walls of extant algae for which fossils may be unknown this implies that they resist the methods that palynologists have used to isolate fossil palynomorphs from sediments. In organic geochemical practice this means that the walls of extant algae must be able to resist base and acid hydrolysis. However, this criterion does not seem to hold since several fossil palynomorphs do not resist such harsh hydrolytic treatments.

There has been considerable confusion on the relation between wall ultrastructure and the occurrence of such 'fossilisable' algal walls. The walls of extant and fossil algae often consist of several layers. For the Chlorophyta, the presence of a trilayered (trilaminar) outer wall is often associated with the presence of hydrolysis resistant walls. However, there is no strict relationship between both features. Species that lack a hydrolysis resistant wall may have a trilaminar wall and vice versa (for a discussion see, de Leeuw and Largeau 1993). 
Furthermore, the different methodologies of isolating the walls of extant algae have led to considerable confusion on the chemical wall structure. This is largely related to artificial polymerisation of the cell contents induced by some isolation methods (Brunner and Honegger 1985; Gelin et al. 1997; Allard et al. 1998). Isoprenoids (e.g. carotenoids), which are highly abundant in many algae, easily become incorporated in these artefacts with the result that isoprenoids have been claimed to be important building blocks of resistant algal cell walls (e.g. Burczyk 1987a, b; Derenne et al. 1996; Kokinos et al. 1998). Despite these problems, there are also early studies e.g. on Botryococcus braunii (Berkaloff et al. 1983) and Tetraedron minimum (Goth et al. 1988), suggesting that such walls are highly aliphatic, i.e. consist of non-cyclic carbon chains which have been cross-linked. Careful re-examination, with more recent technology avoiding the co-analysis of condensed cytoplasm (e.g. by breaking the cell walls prior to chemical treatment), (Brunner and Honegger 1985; Allard et al. 1998; Blokker et al. 1998a) did not confirm this but instead demonstrated either the absence of a resistant wall or the presence of a highly aliphatic cell wall composed of unbranched, but cross-linked carbon atoms, termed algaenan. Consequently, claims in the older literature that a given taxon produces resistant macromolecules, should be evaluated with due consideration. Although not all algae have been subject to such re-examination yet, all evidence suggests that resistant isoprenoidbased biomacromolecules are not produced by modern plants (algae and higher plants).

To date, only two biochemical pathways seem to lead to resistant algal walls (and resistant plant macromolecules in general): (I) the acetate-malate pathway (leading via lipid-synthesis to algaenans, cutin and cutan), and (II) the phenylpropanoid pathway (leading to e.g. sporopollenin, and probably dinosporins). However, we have to acknowledge that only a very limited portion of the living and fossil algae has been studied for the presence and composition of acid and base resistant cell walls. Most species belong to the Chlorophyta and most are from fresh water environments. The marine realm, with the richest and longest fossil record, has hardly been exploited. New pathways leading to fossilisable biomacromolecules may therefore still await discovery. Despite this bias it is clear that only a
Table 1. Microalgae and their fossil palynomorphs.

\begin{tabular}{ll}
\hline Bacillariophyta & - (but ++ record \\
Chlorarachniophyta & - \\
Chloromonadophyta & - \\
Chlorophyta & + (mainly freshwater \\
& Chlorococcales and \\
& mesospores of Zygnematales) \\
Cryptophyta & - \\
Dinophyta & ++ (mainly marine, \\
& very abundant long and \\
Euglenophyta & diverse record) \\
Eustigmatophyta & + (but very rare) \\
Haptophyta & - \\
& - (but ++ for record of \\
Prasinophyta & CaCO \\
Xanthophyta & + \\
Acritarcha & - \\
& ++ (mainly marine, many \\
& Palaeozoic and earlier taxa. \\
& Polyphyletic) \\
\hline
\end{tabular}

few living taxa are capable of producing such walls (Table 1).

\section{Fossilised walls of micro-algae}

From the above it is clear that the presence of cell contents hampers the isolation and analysis of cell walls of living algae. This problem is absent for analysis of fossil palynomorphs. However, three other difficulties complicate the evaluation of fossil algal walls. First, isolating pure, monotypic assemblages is difficult. The unusually high abundance of Pediastrum fossils $(60 \%$ of the palynomorphs) in a late Miocene sediment led to the conclusion that the Pediastrum walls contain aromatic or partly aromatic compounds (Sinninghe Damsté et al. 1993) contradicting later analyses indicating an aliphatic wall for this taxon (Blokker et al. 2000). Second, the lack of recent counterparts, as is the case for the Acritarcha. Third, the transformation of the original biomacromolecule into a geomacromolecule which would provide an alternative explanation to contamination for explaining the results on the Miocene Pediastrum walls. At least, if we assume that aromatic moieties 'invaded' the originally aliphatic biomacromolecule post-mortem. Despite these problems, very close morphological and chemical correspondence does occur between fossil algae and their living counterparts, e.g. for T. minimum (Goth et al. 
1988). This demonstrates that algaenans can survive relatively unchanged in sediments for millions of years.

Compared with algal diversity in present time, the fossil record is severely incomplete. Some algal groups seem to leave no, or almost no, fossils, e.g. like the Euglenophyta (Gray and Boucot 1989). Others leave lipids (e.g. Eustigmatophyta) and/or biominerals (e.g., Bacillariophyta and Haptophyta) but are unknown as fossil palynomorphs. However, some extant Eustigmatophyta and Chlorophyte taxa without known micro-fossil record have been shown to produce hydrolysis resistant walls. It seems likely that their fossil cell walls are present in the sediments but have not been recognised for a lack of morphological characteristics. The ubiquitous presence of 'ultralaminae' with an aliphatic nature in sediments corroborates with this idea (Derenne et al. 1991). Of the algal groups that have been identified from the fossil record, the palynomorphs of Prasinophyta and Chlorophyta are known from the Proterozoic (Knoll 1992, 1996) and continue to the present day. Their fossil records are, however, not very diverse (Batten and Grenfell 1996; Batten 1996; Guy-Ohlson 1996; van Geel and Grenfell 1996; Wicander et al. 1996). Only one, still existing, group of algae, the dinoflagellates, is known to have given rise to a diverse record of largely marine microfossils since the early Mesozoic (Fensome et al. 1999). A second rich and diverse group of fossil palynomorphs is the Acritarcha. This group consists entirely of taxa with an unknown biological affinity but is considered to include a large proportion of palynomorphs from micro-algae. Acritarchs have been found in Precambrian and younger strata. They reached particularly high diversity during the Palaeozoic (Strother 1996). It must be noted that the fossil record from lacustrine environments is much more limited that that from marine environments so that the preservation potential of fresh water algae (notably Chlorophyta) must be underestimated.

\section{Algaenans \\ Algaenans of extant micro-algae}

Algaenans (Tegelaar et al. 1989) represent a series of acid and base-resistant aliphatic biomacromole- cules. It is important to note that other compounds may be associated with the algaenan e.g. isoprenoids in the case of $B$. braunii race $L$ (Bertheas et al. 1999) or sugars in the case of Coelastrum sphaericum (Rodríguez et al. 1999) but they are removed upon hydrolysis. The aliphatic nature suggests that algaenans are biosynthesised via the acetate/malate pathway which leads to FAs. Algaenans appear widespread in Chlorophyta and have been detected in some Eustigmatophyta and a member of the Dinophyta but have not been detected in Bacillariophyta or Haptophyta (Table 2). The walls of some Prasinophyta and the pellicles of several Dinophyta have also been reported to be resistant (e.g. Morrill and Loeblich III 1981; Aken and Pienaar 1985) but information on the wall chemistry is too sparse to infer that they consist of algaenan. For the few more closely analysed algae, three general algaenan structures have been proposed. For most Chlorophyta for which structural information is available, the building blocks consist of linear $\mathrm{C}_{22}$ to $\mathrm{C}_{34}$ even-numbered carbon chains with functional groups at the $\alpha, \omega, \omega^{9}$ and sometimes $\omega^{18}$ positions. In the algaenan the functional groups cross-link the monomers with ether and ester bonds (Blokker et al. 1998a, 1999). However, the algaenan of the Chlorophyte B. braunii, (at least race A) seems to be based on unsaturated aliphatic aldehydes and unsaturated hydrocarbons with on average 40 carbon atoms. Here, the monomers are cross-linked by acetal and ester bonds (Simpson et al. 2003). The third algaenan type proposed is produced by the Eustigmatophyta. Here, the building blocks are probably mid-chain $\left(\omega^{15}\right.$ to $\left.\omega^{18}\right) \mathrm{C}_{28}$ to $\mathrm{C}_{36}$ diols and $\mathrm{C}_{30}$ to $\mathrm{C}_{32}$ alkenols, as well as $\mathrm{C}_{25}, \mathrm{C}_{27}$, and $\mathrm{C}_{29}$ (poly)unsaturated free hydrocarbons which in the algaenan are cross-linked with mid-chain ether bonds (Gelin et al. 1997). Algaenans are among the most frequently studied resistant algal macromolecules. They are mostly isolated from actively growing cultures. The active metabolism implies that the algaenan walls must contain pores to exchange compounds with the outer environment. Despite such pores, algaenan walls have been shown to form an effective barrier for extracellular enzymes (e.g. Atkinson Jr et al. 1972; Syrett and Thomas 1973) and detergents (Biedlingmaier et al. 1987; Corre et al. 1996).

During a phase of quiescence, the reduced metabolic activity allows for much less exchange with the outer environment. These cyst walls could 


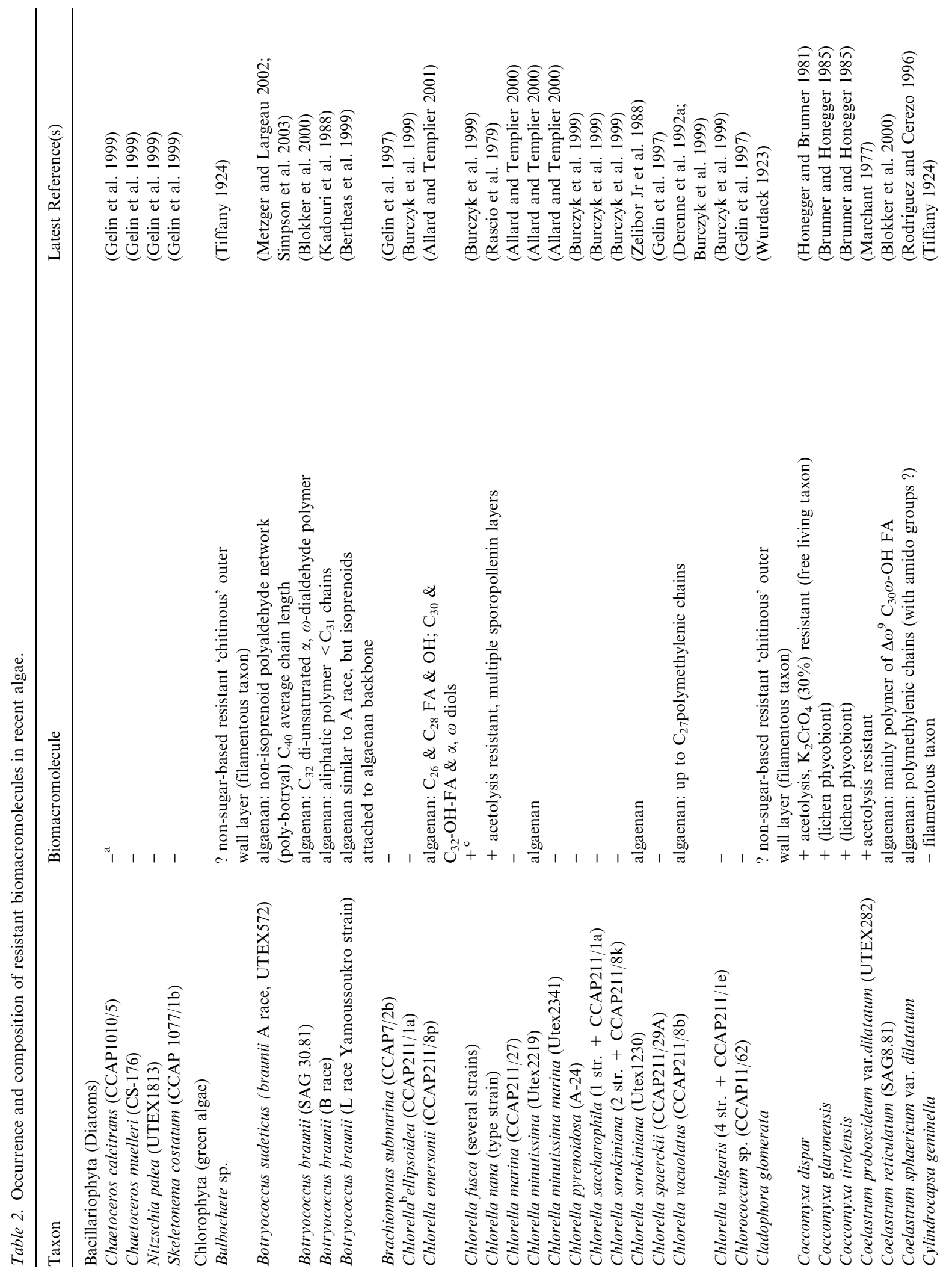




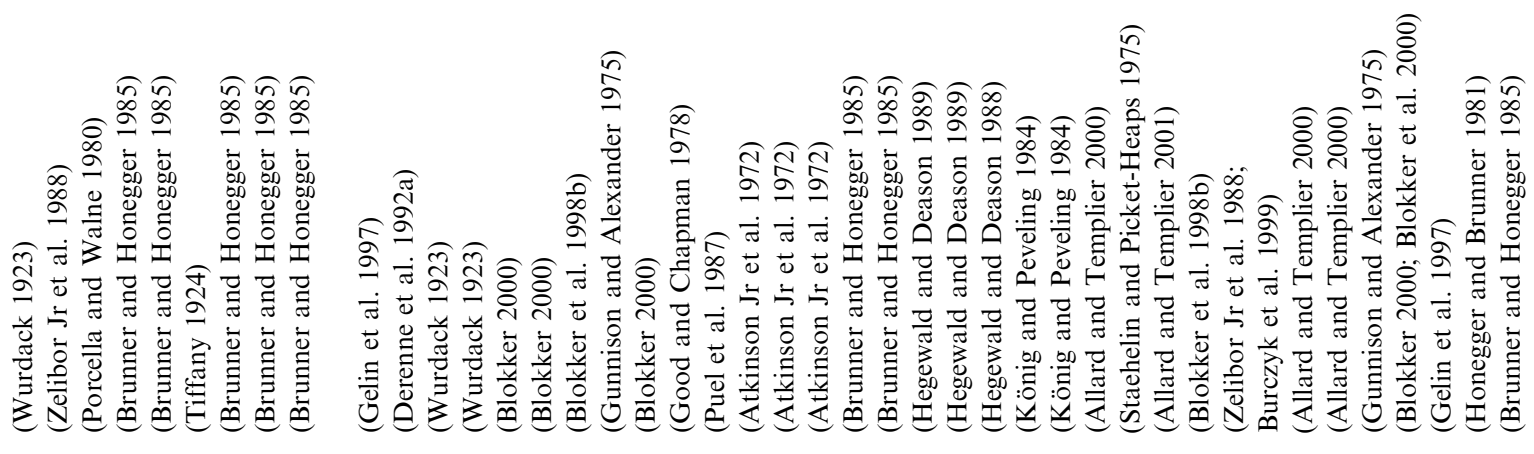
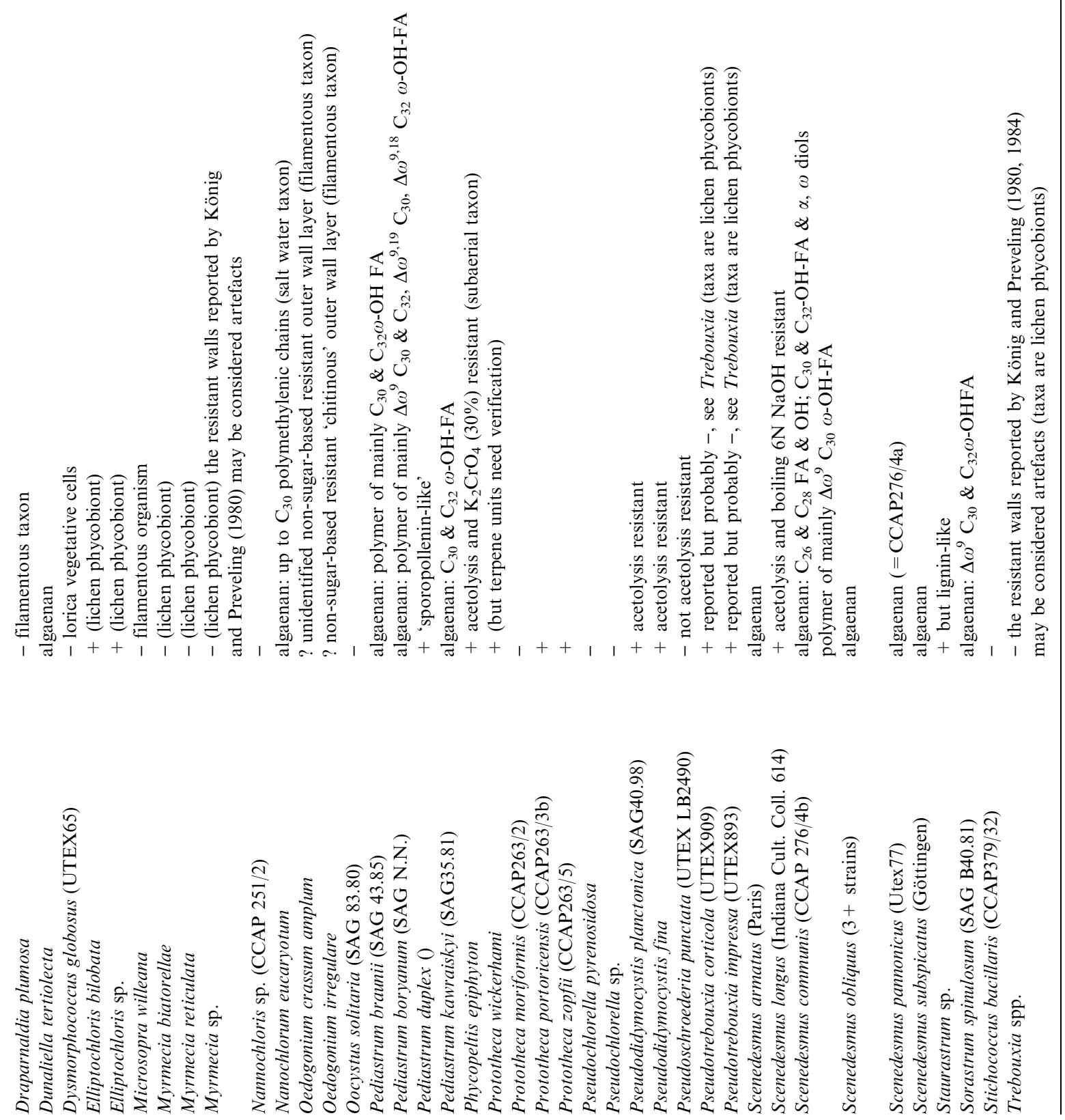


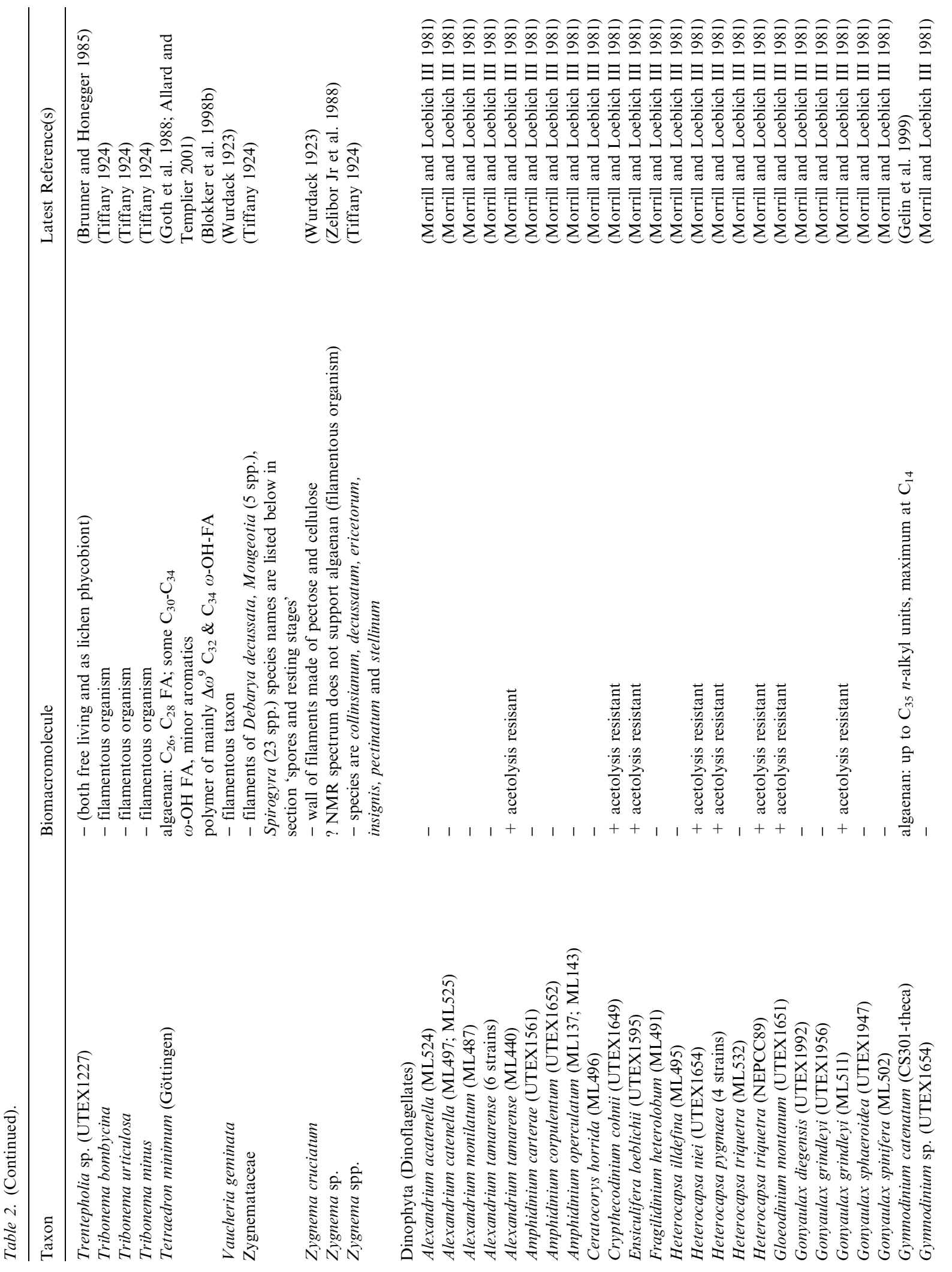




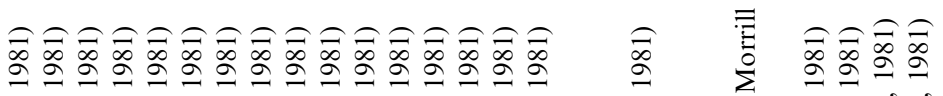

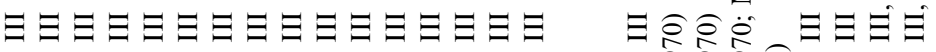

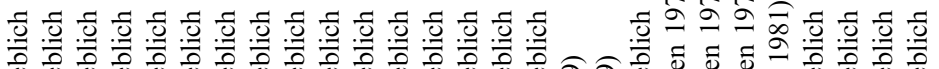
SmWhin

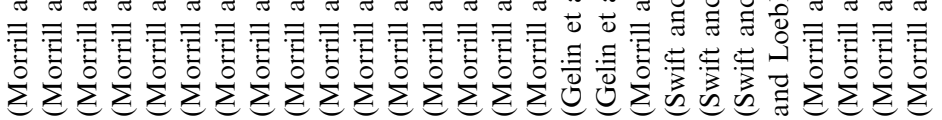

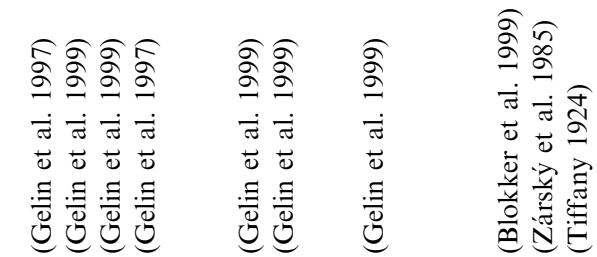
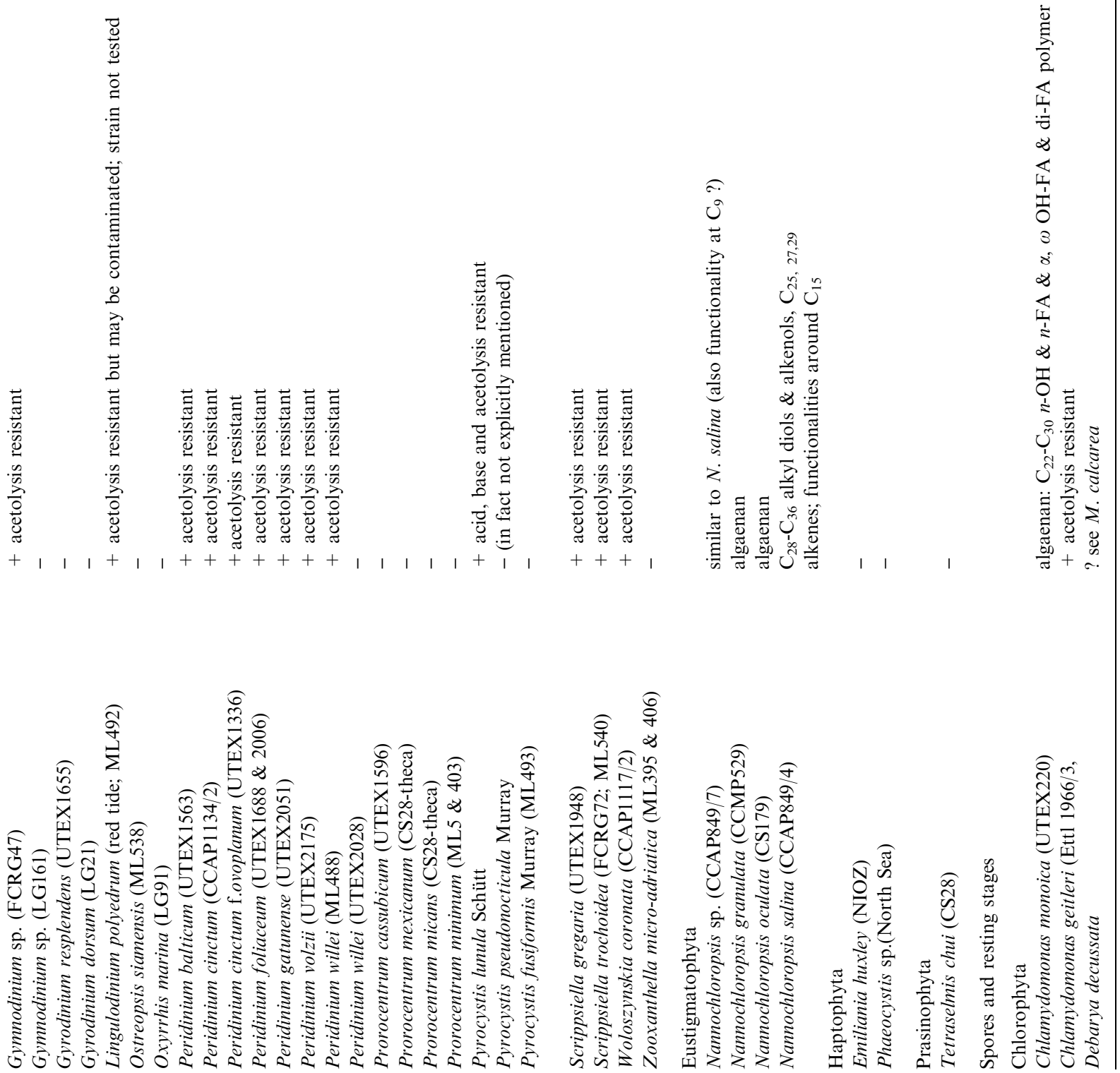


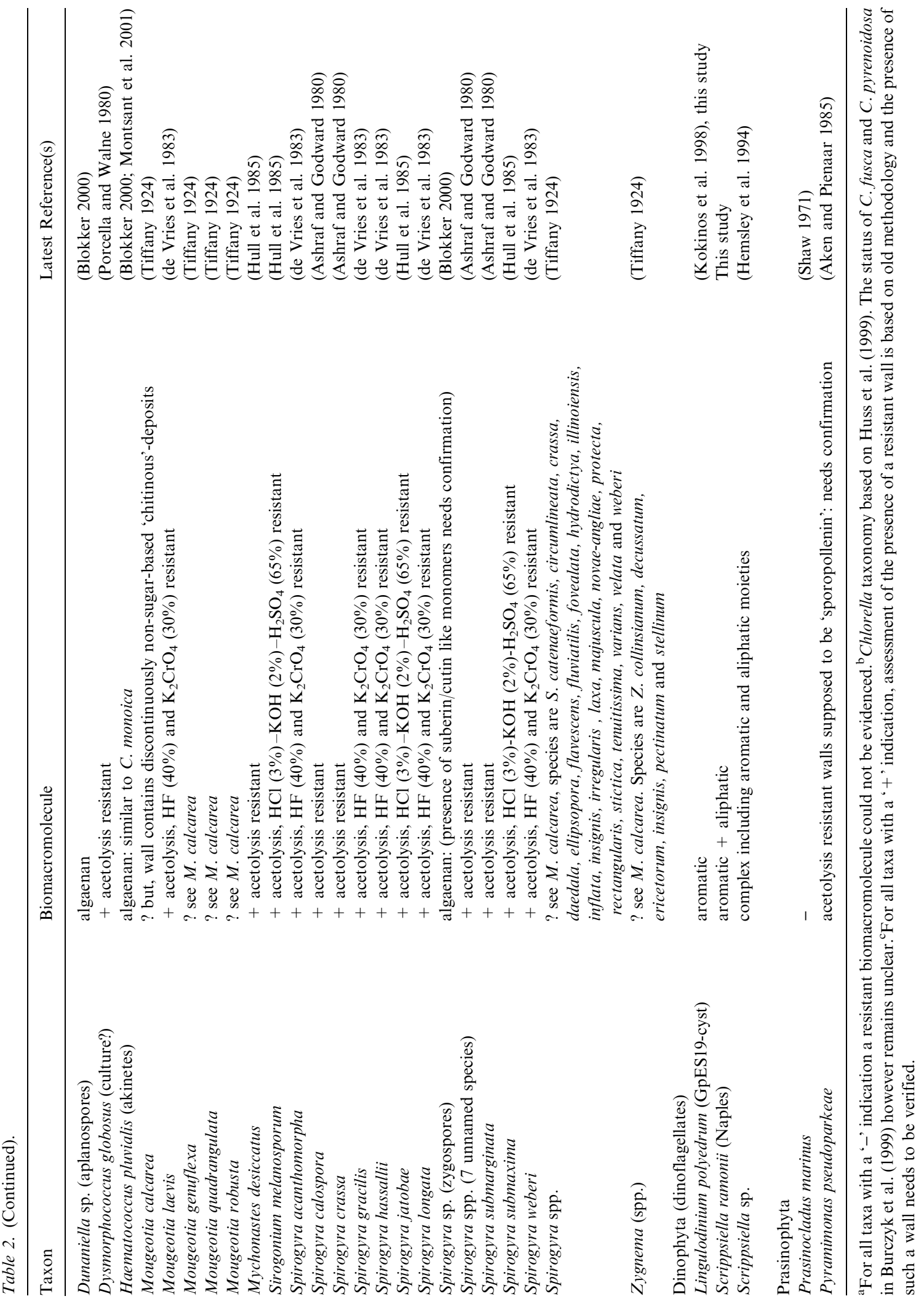


help to survive dryness during aerial dispersion or dry periods (e.g., Haematococcus pluvialis), and/or they could be more resistant to attack if the cysts form a 'seed bank'. Clearly, the constraints set to cell walls of metabolically active and quiescent algae may be very different. Nevertheless, for the Chlorophyta, this does not seem to have had an effect on the wall chemistry. All resting stages analysed also have algaenan walls. The possible presence of aromatic moieties in the algaenan of Spirogyra sp. mesospores, however, needs further investigation (Blokker 2000). Interestingly, in extant algae, algaenans have almost exclusively been detected for fresh water species. The highly aliphatic (plastic like) algaenan may function as a relatively water-proof layer. Such a layer might be an important adaptation for fresh water species or species that live in smaller enclosed habitats; it enables them to spread from one place to another (by wind, birds etc.) and to resist periods of dryness. Most marine species would not necessarily need this.

\section{Fossil algaenans and algaenan-likes}

Only a few fossil algal-walls have been shown to closely resemble their Modern algaenan counterparts. These are all derived from the Chlorophyta (Table 3). To what extent did, the hypothesised migration of aliphatic moieties into the algaenan and the process of oxidative polymerisation attaching the aliphatic moieties to the algaenan (Versteegh et al. 2004) (analogous to the process proposed for changing sporopollenin and cutan above) turn the original algal wall into its present state? Due to the aliphatic nature of the algaenan itself, these processes usually remain unnoticed with current methodology. Seen in this light, the mainly aliphatic nature reported for some Proterozoic acritarchs (Arouri et al. 1999) should be interpreted with care. The additional presence of aromatic and (unusual) amide groups in the walls of these acritarchs, generate questions on the purity of the material, the extent to which the acritarch geomacromolecule still represents the original biomacromolecule and the degree to which this original biomacromolecule was aromatic. For this very old material, a second process, like the removal of aliphatic moieties from the acritarch wall at elevated temperature and pressure conditions may addition- ally have influenced the wall composition. For obvious reasons, this second process has been subject to intense study in relation to understanding oil and gas formation (e.g. Combaz 1971; Rullkötter, 1993) and will therefore not be discussed further.

The acritarch Gloeocapsomorpha prisca (see, Wicander et al. 1996 for an overview) is the principal component of middle Ordovician marine oil shales (kukersites). The taxonomic position of G. prisca has been a matter of considerable debate. On the basis of morphological comparison with modern organisms, it has been assigned mostly to the Cyanobacteria and Chlorophyta, notably the fresh water species $B$. braunii which when cultured under salt stress produces structures that are morphologically similar to those of $G$. prisca (Derenne et al. 1992b). Recent chemical analyses (Blokker et al. 2001; Lille 2003) indicate an aliphatic wall composed of 1,3-benzediol (resorcinol) building blocks with mainly $\mathrm{C}_{15}, \mathrm{C}_{17}$, and $\mathrm{C}_{19}$ alkyl side chains. Resorcinols are known from a variety of higher plants, mosses, fungi, bacteria. They have also been identified as free lipids from Botryococcus (with $\mathrm{C}_{25}-\mathrm{C}_{29}$ alkyl chains) (Metzger and Largeau 1994). Upon salt stress the contribution of phenols to Botryococcus pyrolysates increases (Derenne et al. 1992b) but if these phenols were derived from resorsinols or not, remains to be investigated. Fossil Botryococcus differ from $G$. prisca in lacking evidence for an aliphatic macromolecular wall structure and the shorter chain lengths of the $n$-alkyl resorcinol building blocks of the fossil macromolecule (Blokker et al. 2001).

Moreover, in the light of the widespread occurrence of resorcinols in organisms their occurrence in Botryococcus forms no argument to consider $G$. prisca a member of the Chlorophyta. Resorcinols are produced via the polyketide or acetogenic pathway (Kozubek and Tyman 1999). Depending on the phylogenetic position of G. prisca this could represent a third pathway in algae for the biosynthesis of resistant macromolecules. However, Blokker et al. (2001) indicate that G. prisca may have produced resorcinols for UV and/or microbial protection. They further suggest that the high reactivity of the resorcinols favours their polymerisation, e.g. catalysed by oxygen or trace metals, and that the fossilised macromolecule may have been formed post-mortem. Instead of representing a third biosynthetic pathway, this would provide a 
Table 3. Composition of resistant biomacromolecules in fossil algae.

\begin{tabular}{|c|c|c|c|}
\hline Taxon & Biomacromolecule & Age & Latest Reference(s) \\
\hline \multicolumn{4}{|l|}{ Acritarchs } \\
\hline Reduviasporonites & $\begin{array}{l}\text { mainly aliphatic and minor } \\
\text { aromatic components } \\
\text { filamentous taxon }\end{array}$ & $\mathrm{P} / \mathrm{T}$ boundary & (Foster et al. 2002) \\
\hline Gloeocapsomorpha prisca & $\begin{array}{l}\text { algaenan: mainly } \mathrm{C}_{21} \& \\
\mathrm{C}_{23} n \text {-alkyl } \\
\text { resorcinol polymer }\end{array}$ & Ordovician & $\begin{array}{l}\text { (Blokker et al. 2001; } \\
\text { Lille, 2003) }\end{array}$ \\
\hline Leiosphaeridia & aliphatic & $\begin{array}{l}\text { Silurian and } \\
\text { Ordovician }\end{array}$ & (Kjellström 1968) \\
\hline Multifronsphaeridium peliorum & $\begin{array}{l}\text { manly aliphatic, also aromatic } \\
\text { and amide groups }\end{array}$ & Neoproterozoic & (Arouri et al. 1999) \\
\hline Species A & $\begin{array}{l}\text { manly aliphatic, also aromatic } \\
\text { and amide groups }\end{array}$ & Neoproterozoic & (Arouri et al. 1999) \\
\hline 1.Tanarium sp. A & $\begin{array}{l}1-3 \text { acanthomorph, multilayered } \\
\text { fibrillar wall }\end{array}$ & & \\
\hline 2. Hocosphaeridium scaberfacium & 4-6 no wall layering & & \\
\hline 3. Alicesphaeridium medusoidum & $\begin{array}{l}1-6 \text {, no pyrolysates available, } \\
\text { but IR and Raman }\end{array}$ & Neoproterozoic & (Arouri et al. 2000) \\
\hline 4. Species C2 & $\begin{array}{l}\text { Spectroscopy indicates a } \\
\text { highly ordered aromatic }\end{array}$ & & \\
\hline 5. Chuaria circularis & $\begin{array}{l}\text { biopolymer which can also } \\
\text { be ascribed to over- }\end{array}$ & & \\
\hline 6. Leiosphaeridia $\mathrm{sp}$. & maturity of the organic matter. & & \\
\hline \multicolumn{4}{|l|}{ Chlorophyta } \\
\hline Botryococcus braunii & $\begin{array}{l}\text { aliphatic, like recent } \\
\text { representatives } \\
\text { (isoprenes questionable) }\end{array}$ & Permian to Recent & $\begin{array}{l}\text { (Derenne et al. 1994; } \\
\text { 1997) }\end{array}$ \\
\hline Tetraedron minimum & aliphatic, like recent representative & Eocene (Messel $45 \mathrm{Ma})$ & (Blokker et al. 2000) \\
\hline Pediastrum & aliphatic, like recent $P$. boryanum & Early Holocene (10 ka) & (Blokker et al. 2000) \\
\hline Coelastrum reticulatum (inferred) & aliphatic, like recent representative & Early Holocene (10 ka) & (Blokker et al. 2000) \\
\hline \multicolumn{4}{|l|}{ Prasinophyta } \\
\hline Tasmanites & $\begin{array}{l}\text { polymer of aliphatics, } \\
\text { (+ isoprenoids and aromatics?) } \\
\text { Permian }\end{array}$ & & $\begin{array}{l}\text { (Collinson et al. 1994; } \\
\text { Greenwood et al. 2000) }\end{array}$ \\
\hline Dinophyta & Biomacromolecule purity $^{\mathrm{a}}$ & Age & Reference \\
\hline Brigantedinium spp. & aliphatic/aromatic 83 & $\pm \mathrm{E} /$ Oboundary & (Dammers 2003) \\
\hline Chiropteridium spp. & aliphatic/aromatic $95(97)$ & Oligocene & This study \\
\hline Deflandrea $\mathrm{sp}$. & aliphatic/aromatic $74(75)$ & Middle Eocene & (Warnaar 2001) \\
\hline Enneadocysta sp. & aliphatic/aromatic $89(92)$ & Middle Eocene & (Warnaar 2001) \\
\hline Nematosphaeropsis labyrinthus & aromatic 63 & $\pm 77500 \mathrm{y}$ & (Dammers 2003) \\
\hline Manumiella druggii & aliphatic/aromatic $>75$ & $\pm \mathrm{K} / \mathrm{T}$ boundary & This study \\
\hline Palaeoperidinium spp. & aliphatic/aromatic 88 & $\pm \mathrm{K} / \mathrm{T}$ boundary & (Dammers 2003) \\
\hline Polysphaeridium zoharii & aromatic 76 & $\pm 50000 \mathrm{y}$ & (Dammers 2003) \\
\hline Spiniferites sp.(D3) & aliphatic/aromatic $(>50 \%)$ & $\pm \mathrm{K} / \mathrm{T}$ boundary & (van Mourik 2000) \\
\hline Thalassiphora $\mathrm{sp}$. & aliphatic/aromatic 42(60) & Middle Eocene & (Warnaar 2001) \\
\hline Trithyrodinium evittii (D2; D4) & aliphatic/aromatic $(95 ; 90 \%)$ & $\pm \mathrm{K} / \mathrm{T}$ boundary & (van Mourik 2000) \\
\hline $\begin{array}{l}\text { Mixed gonyaulacoids }{ }^{b} \text { (D1; } \\
\text { GMB-A) }\end{array}$ & aliphatic/aromatic? 73 & $\pm \mathrm{K} / \mathrm{T}$ boundary & (van Mourik 2000; Warnaar 2001) \\
\hline 'Dinocasts' & $\begin{array}{l}\text { aliphatic } \mathrm{C}_{16} \text { and } \mathrm{C}_{18} 100 \\
\text { fatty-acid-based geopolymer }\end{array}$ & Eocene & (Versteegh et al. 2004) \\
\hline
\end{tabular}

${ }^{\text {a}}$ Purity indication denotes the percentage of cysts of the indicated taxon on organic particles (between brackets the percentage of dinoflagellate cysts on organic particles).

${ }^{\mathrm{b}}$ The mixture includes Areoligera senonensis, Cribroperidinium sp., Glaphyrocysta perforata, Hystrichosphaeridium sp., Spiniferites ramosus. 
second example of oxidative polymerisation of algae, analogous to the recent findings of Versteegh et al. (2004). The possibility that the organism excreted the resorcinols to form a protective layer, by oxidative polymerisation, can not be ruled out though.

Tasmanites, represents the only fossil member of the Prasinophyta studied for its wall composition. Pyrolysis of an extracted Tasmanite coal, almost entirely consisting of Tasmanites, by Collinson et al. (1994) and nuclear magnetic resonance (NMR) analysis of HF treated and picked Tasmanites specimens (Hemsley et al. 1993) indicate that these fossils predominantly feature alkane/alkene doublets in the GC-FID trace and thus, that the Tasmanites walls could be made of algaenan, confirming the early suggestion of Kjellström (1968) that the walls consist of long chains of aliphatic saturated hydrocarbons. However, Greenwood et al. (2000) report that the solvent extracted walls are 'comprised of ubiquitous $n$-alkane/alkene, parent and alkyl aromatics, and tricyclic terpenoids' on the basis of GC-MS analysis. They also noted that the untreated parent Tasmanite oil shale has the same composition as Tasmanites. We attribute this discrepancy to the higher ionisation efficiency of aromatics and isoprenoids compared to aliphatics, resulting in underrepresentation of the latter upon mass spectrometry. Therefore, we infer that Tasmanites indeed largely consists of aliphatic moieties. Moreover, the formation of aromatic moieties from isoprenoids since the Permian may explain the aromatic signature of the material. The absence of acid or base hydrolysis treatments of the Tasmanites furthermore leaves the possibility that the isoprenoids became attached to the wall macromolecule post mortem via ester bonds. Analogous to all other fossil and recent walls of algae analysed we suggest that the isoprenoids did not form cell wall constituents. Greenwood et al. (2000) suggest on the basis of the same composition of parent Tasmanite and Tasmanites that the isoprenoids are wall derived, we rather would like to propose the opposite, i.e. that the isoprenoid moieties have become attached to the Tasmanites wall. Based on the results of Kuypers et al. (2002), it can be speculated that apart from Tasmanitesderived also the degradation resistant archaeal isoprenoid membrane lipids have become oxygen cross-linked and contributed to the macromolecular isoprenoid constituent in these samples.

\section{Dinosporins}

\section{Dinosporin of extant dinoflagellates}

In contrast to the algaenan wall of the motile stage of the dinoflagellate Gymnodinium catenatum, (Gelin et al. 1999) dinoflagellates seem to be able to produce a completely different kind of wall for their resting cysts, called dinosporin (Fensome et al. 1993). There is only very limited information on recent dinoflagellate cyst walls. The walls of $L$. polyedrum are reported to be relatively condensed and predominantly aromatic, compositionally distinct from 'sporopollenin', unrelated to the walls of green algae (algaenan) and that the isoprenoid tocopherol as an important monomer (Kokinos et al. 1998). Upon re-analysis using the methodology of Blokker et al. (1998a; Figure 4) these conclusions are confirmed with the exception that no evidence of isoprenoids is observed in the pyrolysates. The discrepancy may be attributed to the phosphoric acid treatment (3 weeks) during the cyst wall isolation procedure by Kokinos et al. (1998) which has been shown to produce artefacts (see for a review, Allard et al. 1998; Allard and Templier 2000). Our pyrolysates show few, short chain $\left(\mathrm{C}_{6}-\mathrm{C}_{10}\right)$, carbon chains and a dominance of mono- to poly-methylated aromatic fragments. Longer chain alkyl benzenes (e.g., butyl-benzene) are virtually absent as is any evidence of alkane/ alkene doublets which is so characteristic for algaenans. Clearly, the cyst walls consist of a dense aromatic network in which few short alkyl chains are intercalated (dinosporin) which is, in agreement with Kokinos et al. (1998), totally different from the aliphatic algaenans. Considering the highly aromatic nature of the cyst biomacromolecule, we propose the phenylpropanoid pathway as the most logical one for the synthesis of its precursors. NMR analysis of Scrippsiella sp. cysts suggests for this taxon a very complex cyst wall macromolecule with also a substantial aliphatic component (Hemsley et al. 1994). Our preliminary analysis of the transparent cyst-walls from a culture of the peridinioid Scrippsiella ramonii confirms this. Both aromatic and aliphatic moieties are observed. Isoprenoid moieties are, however, absent (Figure 5). A series of alkane/alkyl doublets (up to $\mathrm{C}_{18}$ ) and their corresponding ketones (not shown) are present. Interestingly, the aliphatic and aromatic moieties overlap in the sense 
(a) Lingulodinium polyedrum

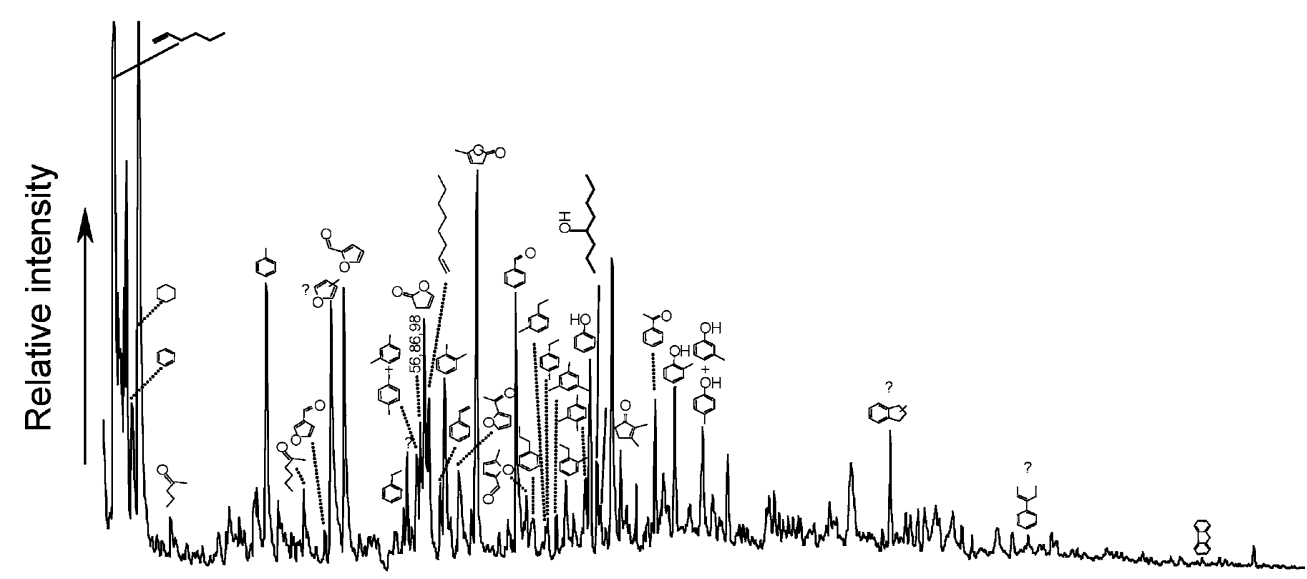

(b) Lingulodinium polyedrum + TMAH

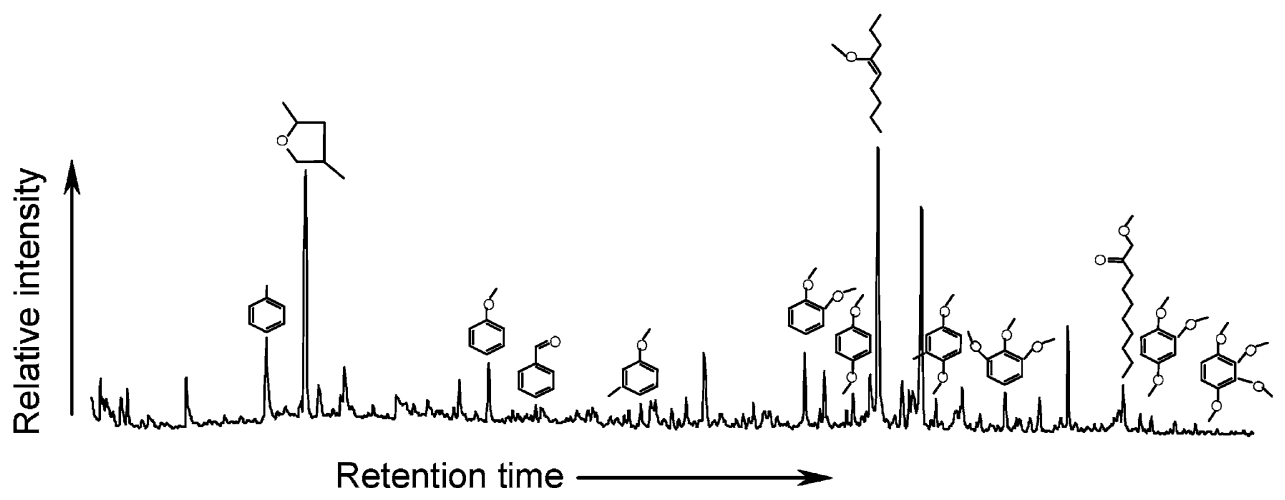

Figure 4. a. Pyrolysate of Lingulodinium polyedrum cyst walls from cultured material. b. Pyrolysate of Lingulodinium polyedrum cyst walls using tetramethylammonium hydroxide (TMAH). Upon thermolysis the TMAH methylates the oxygen radicals preventing secondary reactions of the pyrolysis products. Both panels demonstrate the aromatic nature of the walls. Note also the absence of isoprenoid moieties.

that also a series of alkyl-benzenes (up to $\mathrm{C}_{7}$ ) is present but there is no trace of resorcinols. These latter observations suggest that the aliphatic and aromatic moieties are not organised in separate layers of the cyst wall but are mixed. However, the extent to which the alkyl-benzenes can be formed from aromatic and aliphatic pyrolysis products still remains to be investigated and thus can not be excluded either. Finally, $\mathrm{C}_{14}$ and $\mathrm{C}_{16}$ FAs are prominent in the pyrolysate whereas the $\mathrm{C}_{18} \mathrm{FA}$ is absent. This absence of the $\mathrm{C}_{18}$ FA makes contamination unlikely as well as a contribution of free, dinoflagellate derived, lipids or their salts (Hartgers et al. 1995) since the $\mathrm{C}_{18} \mathrm{FA}$ is also prominent in the free lipid extract. Upon pyrolysis with TMAH the $\mathrm{C}_{14}$ and $\mathrm{C}_{16}$ FAs reappear prominently. However, a series of distally unsaturated and $\alpha, \omega$-dicarboxylic acids are also present suggesting that the aliphatic moieties are part of the biomacromolecular network and represent FA monomers bound to the macromolecule.

The chemical and geological stability of the cysts informs us on a different aspect of dinoflagellate cyst walls. In marine palynology, strong acids, acetolysis and base treatment are avoided as much as possible upon processing of dinoflagellate assemblages from sediments. The reason is that although most gonyaulacoid cysts (the group to which Lingulodinium belongs) resist such treatments, they destroy many protoperidinioid cysts (the group to which Scrippsiella belongs), notably the brown-walled taxa (e.g. Dale 
Lingulodinium polyedrum

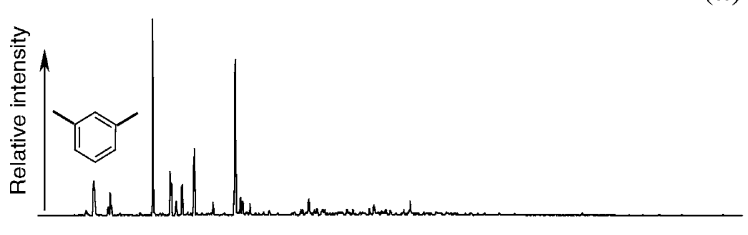

Scrippsiella ramonii

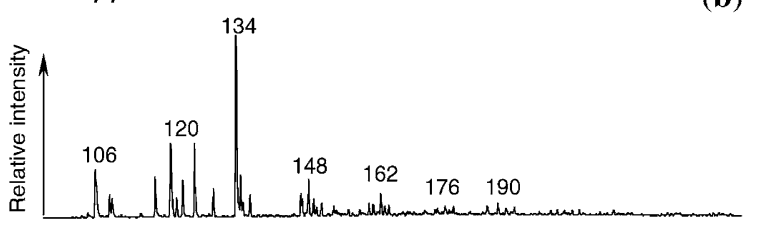

Chiropteridium

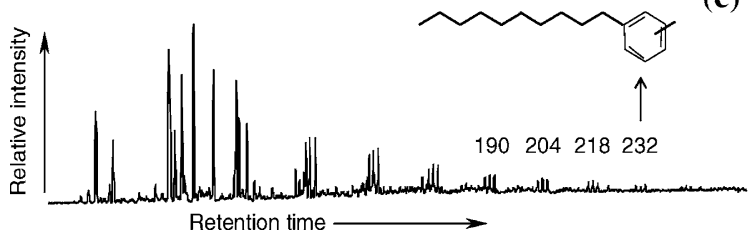

(c) (a)

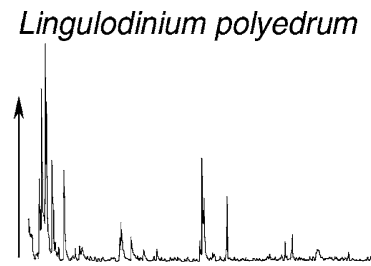

Scrippsiella ramonii

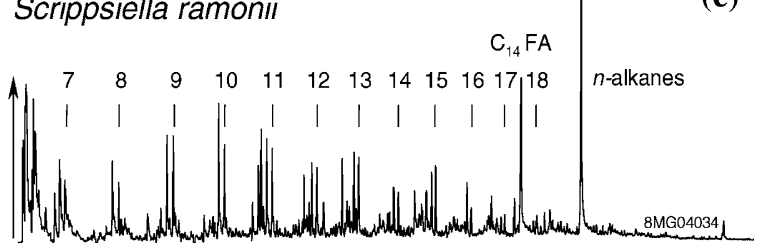

Chiropteridium

(f)

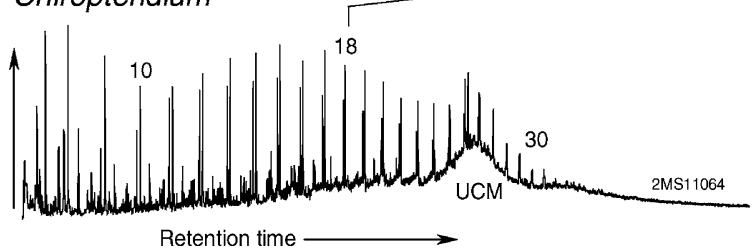

Figure 5. Pyrolysate mass chromatograms of a, b. Lingulodinium polyedrum cysts from cultures, c, d. Scrippsiella ramonii cysts from cultures, e, f. Chiropteridium cysts from Oligocene sediments. $m / z 105$ (a,c,e) showing the methyl-, alkyl-benzenes and $m / z 55+57$ (b,d,f) showing the aliphatic moieties, notably alkene/alkane doublets. Numbers in panels c, e refer to the $M^{+}$of the corresponding components. $\mathrm{FA}=$ fatty acid, $\mathrm{UCM}=$ unresolved complex mixture.

1976; Turon 1984; Schrank 1988; Marret 1993; Hopkins and McCarthy 2002; and pers. obs.). This suggests that the gonyaulacoid macromolecule consists of a high proportion of carbon and etherlinked building blocks whereas the building blocks of protoperidinioid macromolecules are much more ester linked. Interestingly, in the sediments, the resistance of cysts to oxidation parallels their resistance to chemical treatment in the laboratory (Zonneveld et al. 1997, 2001; Versteegh and Zonneveld 2002).

On the basis of the above we conclude that there are probably two variables influencing dinosporin composition, the proportion of aliphatic $v s$. aromatic moieties and the proportion of ether- and carbon-bonds vs. ester-bonds. We further hypothesise that these two variables covary and relate to cyst preservation such that the chemically and/or geologically more resistant cysts (c.f. L. polyedra) have more aromatic moieties and more etherbonds connecting these moieties than the less resistant ones (c.f. S. ramonii). However, this hypothesis urgently needs further testing. A major problem in achieving this is that many organic-cyst forming dinoflagellates are notoriously difficult to culture and that inducing cyst formation in culture in sufficient is technically challenging.

We speculate that the presence of aromatic moieties in the cyst wall relates to the fact that they are resting cysts. Some taxa are known to survive in the sediments for more than a decade (Lewis et al. 1999). The cysts are metabolically almost completely inactive (Binder and Anderson 1990) but simultaneously have to protect themselves against bacterial and fungal attack. The aromatic moieties may function as toxins, similar to flavins and tannins in higher plants. Interestingly, this implies that a positive correlation may exist between the survival period of the encysted organism in the sediment, the chemical composition of the cyst wall and its fossilisation potential.

\section{Fossil dinosporin}

In recent years several attempts have been made to obtain pure dinoflagellate cyst fractions from sediments, starting in the early 70s (Combaz 1971). In a few cases, high purity was obtained (Table 3 ). 
Pyrolysis of the purest, base- and acid-hydrolysed, fraction with $96 \%$ of the Gonyaulacoid Chiropteridium displays a mixture of aliphatic and aromatic moieties and no isoprenoids. The pyrolysate resembles that of $S$. ramonii but the aliphatic fragments continue to longer chain lengths; alkane/alkene doublets and their corresponding ketones to $\mathrm{C}_{30}$ and the alkylbenzenes up to $\mathrm{C}_{11}$. Furthermore, the FAs are absent. The purity of the sample strongly suggests that the cyst walls are composed of both aliphatic and aromatic moieties. Upon pyrolysis with TMAH, a series of saturated and unsaturated FA moieties is formed, sharply dropping of at $\mathrm{C}_{18}$. The importance of a high purity is illustrated by the observation that analysis of less pure samples yielded highly aliphatic products with the aromatic contribution being strongly dependant on the amount of little black blocky entities in the sample (van Mourik 2000; Warnaar 2001). These black bits yielded predominantly phenols and not only simple aromatics. Clearly, more analyses are needed on pure fossil cyst fractions before and after artificial maturation to elucidate the nature of the fossil cyst walls.

Since the only extant micro-algae known to produce aromatic walls are dinoflagellates, the basically aromatic wall composition of several acantomorph Neoproterozoic Acritarcha has been used to argue that these Acritarcha are related to the dinoflagellates (Arouri et al. 2000). This corroborates with earlier suggestions, based on acritarch morphology (e.g. Sarjeant 1978; Butterfield and Rainbird 1998; Leppig and Montenari 2000), the fossil record of dinosteroids (e.g. Moldowan et al. 1996; Talyzina et al. 2000) and molecular phylogeny (Javaux et al. 2003) that the dinoflagellates originate in the Neoproterozoic.

However, it must be stressed that alternative interpretations are still feasible since the highly aromatic nature of the Neoproterozoic acritarchs may also be related to maturity levels (Arouri et al. 2000), or even convergence.

\section{Concluding remarks}

It is clear that the analysis of recent and fossil resistant biomacromolecules requires extreme care especially with respect to the purification procedures and maturation. For the extant material, avoiding artificial condensation and oxidative polymerisation of cytoplasm and ester-bound moieties requires constant attention. Notably addition of aliphatic moieties may occur. For the fossil material, contamination by organic particles other than the target taxon is hard to eliminate and can contribute to either the aliphatic or aromatic signal. Furthermore, post-mortem migration of aliphatic moieties into, and their condensation onto the macromolecule might occur as well. These things hamper the evaluation of the aliphatic signature of fossil plant material. The extent to which migration and in situ formation of aromatic moieties plays a role in modifying resistant algal macromolecules, notably under elevated temperature and/or pressure conditions, still remains an open question.

\section{Acknowledgements}

We thank Peter Blokker (Free University, Amsterdam) and two anonymous referees for useful suggestions for improvement of the manuscript. Peter Blokker is also thanked for processing and analysing the Lingulodinium and Scrippsiella cysts; Arnoud Boom for providing Figure 2; Arne van Mourik, Jeroen Wanaar and Niels Dammers, Utrecht University for purification and analysis of several fossil dinoflagellate cyst fractions. Jane Lewis and Richard Hallett (University of Westminster, London), are thanked for providing the Lingulodinium cysts, Stefano Torricelli (AGIP ENI, Milan) for providing the purified Chiropteridium sample, and Marina Montresor (Stazione Zoologica, Naples) for providing the Scrippsiella cysts. This is NSG paper 2004.05.08

\section{References}

Aken M.E. and Pienaar R.N. 1985. Preliminary investigations on the chemical composition of the scale-boundary and cyst wall of Pyramimonas pseudoparkeae (Prasinophyceae). S. Afr. J. Bot. 51: 408-416.

Allard B. and Templier J. 2000. Comparison of neutral lipid profile of various trilaminar outer cell wall (TLS)-containing microalgae with emphasis on algaenan occurrence. Phytochemistry 54: 369-380.

Allard B. and Templier J. 2001. High molecular weight lipids from the trilaminar outer wall (TLS)-containing microalgae Chlorella emersonii, Scenedesmus communis and Tetraedron minimum. Phytochemistry 57: 459-467. 
Allard B., Templier J. and Largeau C. 1998. An improved method for the isolation of artifact-free algaenans from microalgae. Org. Geochem. 28: 543-548.

Arouri K., Greenwood P.F. and Walter M.R. 1999. A possible chlorophycean affinity of some Neoproterozoic acritarchs. Org. Geochem. 30: 1323-1337.

Arouri K.R., Greenwood P.F. and Walter M.R. 2000. Biological affinities of Neoproterozoic acritarchs from Australia: microscopic and chemical characterisation. Org. Geochem. 31: $75-89$.

Ashraf M. and Godward M.B.E. 1980. Ultrastructure and chemistry of the zygospore wall of Spirogyra. Ann. Bot. 46: 485-487.

Atkinson A.W. Jr, Gunning B.E.S. and John P.C.L. 1972. Sporopollenin in the cell wall of Chlorella and other algae: ultrastructure, chemistry and incorporation of ${ }^{14} \mathrm{C}$-acetate, studied in synchronous cultures. Planta 107: 1-32.

Batten D.J. 1996. Green and blue-green algae. Colonial Chlorococcales. In: Jansonius J. and McGregor D.C. (eds.), Palynolog: Principles and Applications, AASP Foundation, Salt Lake City, pp. 191-203.

Batten D.J. and Grenfell H.R. 1996. Green and blue-green algae. Botryococcus. In: Jansonius J. and McGregor D.C. (eds.), Palynology: Principles and Applications, AASP Foundation, Salt Lake City, pp. 205-214.

Berkaloff C., Casadevall E., Largeau C., Metzger P., Peracca S. and Virlet J. 1983. The resistant polymer of the walls of the hydrocarbon-rich alga Botryococcus braunii. Phytochemistry 22: 389-397.

van Bergen P.F. 1994. Palaeobotany of Propagules: An Investigation combining Microscopy and Chemistry. Ph.D. Thesis. University of London, London.

van Bergen P.F., Blokker P., Collinson M.E., Sinninghe Damsté J.S. and de Leeuw J.W. 2004. Structural biomacromolecules in plants. What can be learnt from the fossil record?. In: Hemsley A.R. and Poole I. (eds.), Evolution of Plant Physiology, Elsevier, Amsterdam, pp. 133-154.

van Bergen P.F., Collinson M.E., Blokker P., Van Moerkerken P., Barrie P.J. and de Leeuw J.W. Chemical characterization of (fossil) sporopollenin: a molecular comparison of Azolla microspore massulae and Kurtzipites pollen with a review of previous literature, in press.

van Bergen P.F., Collinson M.E., Briggs D.E.G., de Leeuw J.W., Scott A.C., Evershed R.P. and Finch P. 1995. Resistant biomacromolecules in the fossil record. Acta Bot. Neerl. 44: 319-345.

van Bergen P.F., Collinson M.E. and de Leeuw J.W. 1993. Chemical composition and ultrastructure of fossil and extant salvinialean microspore massulae and megaspores. Grana Suppl. 1: 18-30.

Bertheas O., Metzger P. and Largeau C. 1999. A high molecular weight complex lipid, aliphatic polyaldehyde tetraterpenediol polyacetal from Botryococcus braunii (L. race). Phytochem. 50: $85-96$.

Biedlingmaier S., Wanner G. and Schmidt A. 1987. A correlation between detergent tolerance and cell wall structure in green algae. Z. Naturforsch. 42: 245-250.

Binder B.J. and Anderson D.M. 1990. Biochemical composition and metabolic activity of Scripsiella trochoidea (Dinophyceae) resting cysts. J. Phycol. 26: 289-298.
Blokker P. 2000. Structural analysis of resistant polymers in extant algae and ancient sediments. Geol. Ultratrajectina 193: $1-145$.

Blokker P., Schouten S., de Leeuw J.W., Sinninghe Damsté J.S. and van den Ende H. 1999. Molecular structure of the resistant biopolymer in the zygospore cell walls of Chlamydomonas monoica. Planta 207: 539-543.

Blokker P., Schouten S., de Leeuw J.W., Sinninghe Damsté J.S. and van den Ende H. 2000. A comparitive study of fossil and extant algaenans using ruthenium tetroxide degradation. Geochim. Cosmochim. Acta 64: 2055-2065.

Blokker P., Schouten S., van den Ende H., de Leeuw J.W., Hatcher P.G. and Sinninghe Damsté J.S. 1998a. Chemical structure of algaenans from the fresh water algae Tetraedron minimum, Scenedesmus communis and Pediastrum boryanum. Org. Geochem. 29: 1453-1468.

Blokker P., Schouten S., van den Ende H., de Leeuw J.W. and Sinninghe Damsté J.S. 1998b. Cell wall specific $\omega$-hydroxy fatty acids in freshwater green microalgae. Phytochem. 49: 691-695.

Blokker P., van Bergen P., Pancost R., Collinson M.E., de Leeuw J.W. and Sinninghe Damsté J.S. 2001. The chemical structure of Gloeocapsamorpha prisca microfossils: Implications for their origin. Geochim. Cosmochim. Acta 65: 885-900.

Blom A.V. 1936. Quelques remarques sur le mécanisme de séchage des peintures à l'huile. Peintures, Pigments, Vernis 13: $156-162$.

Boom A. 2004. A Geochemical Study of Lacustrine Sediments: Towards Palao-climatic Econstructions of High Andean Biomes in Colombia. University of Amsterdam, Amsterdam, p. 125.

Boom A., Sinninghe Damsté J.S. and de Leeuw J.W. 2005. Cutan, a common aliphatic biopolymer in cuticles of drought-adapted plants. Org. Geochem. 36: 596-601.

Briggs D.E.G., Kear A.J., Baas M., de Leeuw J.W. and Rigby S. 1995. Decay and composition of the hemichordate Rhabdopleura: implications for the taphonomy of graptolites. Lethaia 28: 15-23.

Brunner U. and Honegger R. 1985. Chemical and ultrastructural studies on the distribution of sporopollenin like biopolymers in six genera of lichen phycobionts. Can. J. Bot. 63: $2221-2230$.

Burczyk J. 1987a. Biogenic relationships between ketocarotenoids and sporopollenins in green algae. Phytochemistry 26 : $113-119$.

Burczyk J. 1987b. Cell wall carotenoids in green algae which form sporopollenins. Phytochemistry 26: 121-128.

Burczyk J., Šmietana B., Terminska-Pabis K., Zych M. and Kowalowski P. 1999. Comparison of nitrogen content amino acid composition and glucosamine content of cell walls of various chlorococcalean algae. Phytochemistry 51: 491-497.

Butterfield N.J. and Rainbird R.H. 1998. Diverse organic-walled fossils, including 'possible dinoflagellates' from the early Neoproterozoic of arctic Canada. Geology 26: 963-966.

Collinson M.E., Mösle B., Finch P., Scott A.C. and Wilson R. 1998. Structure, biosynthesis and biodegradation of cutin and suberin. Ancient Biomol. 2: 251-265.

Collinson M.E. and van Bergen P.F. 2004. Evolution of angiosperm fruit and seed physiology: anatomical and chemical evidence from fossils. In: Hemsley A.R. and Poole I. (eds.), Evolution of Plant Physiology, Elsevier, Amsterdam, pp. $343-377$. 
Collinson M.E., van Bergen P.F., Scott A.C. and de Leeuw J.W. 1994. The oil-generating potential of plants from coal and coal-bearing strata through time: a review with new evidence from Carboniferous plants. Geol. Soc. Spec. Publ. 77: 31-70.

Combaz A. 1971. Themal degradation of sporopollenin and genesis of hydrocarbons. In: Brooks J. (ed.), Sporopollenin, Academic Press, London, pp. 621-653.

Corre G., Templier J., Largeau C., Rousseau B. and Berkaloff C. 1996. Influence of cell wall composition on the resistance of two Chlorella species (Chlorophyta) to detergents. J. Phycol. 32: 584-590.

Dale B. 1976. Cyst formation, sedimentation, and preservation: factors affecting dinoflagellate assemblages in recent sediments from Trondheimsfjord. Norway. Rev. Palaeobot. Palynol. 22: 39-60.

Dammers N. 2003. Chemical characterization of the organicwalled dinoflagellate cyst taxa Nematosphaeropsis labyrinthus, Polysphaeridium zoharii, Brigantedinium spp. and Palaeoperidinium spp. and a review on algaenan and dinosterol. Masters Thesis, Department of Geochemistry, Utrecht University, 43 pp.

de Leeuw J.W. and Largeau C. 1993. A review of macromolecular compounds that comprise living organisms and their role in kerogen, coal and petroleum formation. In: Engel M.H. and Macko S.A. (eds.), Organic Geochemistry. Principles and Applications, Plenum Press, New York, pp. 23-72.

de Vries P.J.R., Simons J. and van Beem A.P. 1983. Sporopollenin in the spore wall of Spirogyra (Zygnemataceae, Chlorophyceae). Acta Bot. Neerl. 32: 252-258.

Derenne S., Largeau C. and Behar F. 1994. Low polarity pyrolysis products of Permian to Recent Botryoccus-rich sediments: first evidence for the contribution of an isoprenoid algaenan to kerogen formation. Geochim. Cosmochim. Acta 58: 3703-3711.

Derenne S., Largeau C. and Berkaloff C. 1996. First example of an algaenan yielding an aromatic-rich pyrolysate. Possible geochemical implications on marine kerogen formation. Org. Geochem. 24: 617-627.

Derenne S., Largeau C., Berkaloff C., Rousseau B., Wilhelm C. and Hatcher P.G. 1992a. Non-hydrolysable macromolecular constituents from outer walls of Chlorella fusca and Nanochlorum eucaryotum. Phytochemistry 31: 1923-1929.

Derenne S., Largeau C., Casadevall E., Berkaloff C. and Rousseau B. 1991. Chemical evidence of kerogen formation in source rocks and oil shales via selective preservation of thin resistant outer walls of microalgae: origin of ultralaminae. Geochim. Cosmochim. Acta 55: 1041-1050.

Derenne S., Largeau C., Hetényi M., Brukner-Wein A., Conan J. and Lugardon B. 1997. Chemical structure of the organic matter in a Pliocene maar-type shale: implicated Botryococcus race strains and formation pathways. Geochim. Cosmochim. Acta 61: 1879-1889.

Derenne S., Metzger P., Largeau C., van Bergen P.F., Gatellier J.P., Sinninghe Damsté J.S., de Leeuw J.W. and Berkaloff C. 1992. Similar morphological and chemical variations of Gloeocapsomorpha prisca in Ordovician sediments and cultured Botryococcus braunii as a response to changes in salinity. Org. Geochem. 19: 299-313.

Deshmukh A. P., Simpson A.J. and Hatcher P.G. 1964. Evidence for cross-linking in tomato cutin using HR-MAS NMR spectroscopy. Phytochemistry 64: 1163-1170.
Domínguez E., Mercado J.A., Quesada M.A. and Heredia A. 1999. Pollen sporopollenin: degradation and structural elucidation. Sex. Plant Reprod. 12: 171-178.

Fensome R.A., et al., 1993. A Classification of Modern and Fossil Dinoflagellates. Sheridan Press, Hanover, p. 351.

Fensome R.A., Saldarriaga J.F. and Taylor F.J.R. 1999. Dinoflagellate phylogeny revisited: reconciling morphological and molecular based phylogenies. Grana 38: 66-80.

Fjällström P., Andersson B., Nilsson C. and Andersson K. 2002. Drying of linseed oil paints: a laboratory study of aldehyde emissions. Indust. Crop. Prod. 16: 173-184.

Foster C.B., Stephenson M.H., Marshall C., Logan G.A. and Greenwood P.F. 2002. A revision of Reduviasporonites Wilson 1962: description, illustration, comparison and biological affinities. Palynology 26: 35-58.

Gabarayeva N.I., Blackmore S. and Rowley J.R. 2003. Observations on the experimental destruction and substructural organisation of the pollen wall of some selected Gymnosperms and Angiosperms. Rev. Palaeobot. Palynol. 124: $203-226$.

van Geel B. and Grenfell H.R. 1996. Green and blue-green algae. Spores of Zygnemataceae. In: Jansonius J. and McGregor D.C. (eds.), Palynology: Principles and Applications, AASP Foundation, Salt Lake City, pp. 173-179.

Gelin F., Boogers I., Noordeloos A.A.M., Sinninghe Damsté J.S., Riegman R. and de Leeuw J.W. 1997. Resistant biomacromolecules in marine microalgae of the classes Eustigmatophyceae and Chlorophyceae: Geochemical applications. Org. Geochem. 26: 659-675.

Gelin F., Volkman J.K., Largeau C., Derenne S., Sinninghe Damsté J.S. and de Leeuw J.W. 1999. Distribution of aliphatic nonhydrolyzable biopolymers in marine microalgae. Org. Geochem. 30: 147-159.

Good B.H. and Chapman R.L. 1978. The ultrastructure of Phycopeltis (Chroolepidaceae: Chlorophyta). I. Sporopollenin in the cell walls. Am. J. Bot. 65: 27-33.

Goth K., de Leeuw J.W., Püttmann W. and Tegelaar E.W. 1988. Origin of messel oil shale kerogen. Nature 336: 759-761.

Gray J. and Boucot A.J. 1989. Is Moyeria a euglenoid?. Lethaia 22: $447-456$.

Greenwood P.F., Arouri K.R. and George S.C. 2000. Tricyclic terpenoid composition of Tasmanites kerogen as determined by pyrolysis GC-MS. Geochim. Cosmochim. Acta 64: $1249-1263$.

Guilford W.J., Schneider D.M., Labovitz J. and Opella S.J. 1988. High resolution solid state ${ }^{13} \mathrm{C}$ NMR spectroscopy of sporopollenin from different plant taxa. Plant Physiol. 86: 134-136.

Gunnison D. and Alexander M. 1975. Basis for the resistance of several algae to microbial decomposition. Appl. Microbiol. 29: $729-738$.

Guy-Ohlson D. 1996. Green and blue-green algae. Prasinophyceanalgae. In: Jansonius J. and McGregor D.C. (eds.), Palynology: Principles and Applications, AASP Foundation, Salt Lake City, pp. 181-189.

Hartgers W.A., Sinninghe Damsté J.S. and de Leeuw J.W. 1995. Curie-point pyrolysis of sodium salts of functionalized fatty acids. J. Anal. Appl. Pyrolysis 34: 191-217.

Hayatsu R., Botto R.E., Mcbeth R.L., Scott R.G. and Winans R.E. 1988. Chemical alteration of a biological polymer 'sporopollenin' during coalification: origin, formation, and 
transformation of the coal maceral sporinite. Energy Fuel 2: 843-847.

Hegewald E. and Deason T.R. 1988. Pseudoschroederia punctata (Chlorophyta, Chlorococcales), a new species with an unusual cell wall. Arch. Hydrobiol. Suppl. 78: 465-473.

Hegewald E. and Deason T.R. 1989. Pseudodidymocystis, a new genus of Scenedesmaceae (Chlorophyceae). Arch. Hydrobiol. Suppl. 82: 119-127.

Hemsley A.R., Barrie P.J., Chaloner W.G. and Scott A.C. 1993. The composition of sporopollenin and its use in living and fossil plant systematics. Grana Suppl. 1: 2-11.

Hemsley A.R., Barrie P.J. and Chaloner W.G. 1994. Studies of fossil and modern spore and pollen wall biomacromolecules using 13C solid state NMR. NERC Spec. Publ. 94: $15-19$.

Holloway P.J. 1982. The chemical constitution of plant cutins. In: Cutler D.F. (ed.), The Plant Cuticle, Elsevier, Amsterdam, pp. 45-85.

Honegger R. and Brunner U. 1981. Sporopollenin in the cell walls of Coccomyxa and Myrmecia phycobionts of various lichens: an ultrastructural and chemical investigation. Can. J. Bot. 59: 2713-2734.

Hopkins J.A. and McCarthy F.M.G. 2002. Post-depositional palynomorph degradation in Quaternary shelf sediments: a laboratory experiment studying the effects of progressive oxidation. Palynology 26: 167-184.

Hull H.M., Hoshaw R.W. and Wang J.-C. 1985. Interpretation of zygospore wall structure and taxonomy of Spirogyra and Sirogonium (Zygnemataceae, Chlorophyta). Phycologia 24: 231-239.

Huss V.A.R., Frank C., Hartmann E.C., Hirmer M., Kloboucek A., Seidel B.M., Wenzeler P. and Kessler E. 1999. Biochemical taxonomy and molecular phylogeny of the genus Chlorella sensu lato (Chlorophyta). J. Phycol. 35: 587-598.

Javaux E., Knoll A.H. and Walter M. 2003. Recognizing and interpreting the fossils of early eukaryotes. Origin. Life Evol. Biosph. 33: 75-94.

Kadouri A., Derenne S., Largeau C., Casadevall E. and Berkaloff C. 1988. Resistant biopolymer in the outer walls of Botryococcus braunii, B race. Phytochemistry 27: 551-557.

Kjellström G. 1968. Remarks on the chemistry and ultrastructure of the cell wall of some Palaeozoic leiospheres. Geol. Föreningens Stockholm Förhandl. 90: 221-228.

Knoll A.H. 1992. The early evolution of eukaryotes: a geological perspective. Science 256: 622-627.

Knoll A.H. 1996. Archean and Proterozoic paleontology. In: Jansonius J. and McGregor D.C. (eds.), Palynology: Principles and Applications, AASP Foundation, Salt Lake City, pp. $51-80$.

Kokinos J.P., Eglinton T.I., Goñi M.A., Boon J.J., Martoglio P.A. and Anderson D.M. 1998. Characterisation of a highly resistant biomacromolecular material in the cell wall of a marine dinoflagellate resting cyst. Org. Geochem. 28: 265-288.

Kolattukudy P.E. 1981. Structure, biosynthesis and biodegradation of cutin and suberin. Ann. Rev. Plant Physiol 32: 539-576.

König J. and Peveling E. 1980. Vorkommen von sporopollenin in der zellwand des phycobionten Trebouxia. Z. Pflanzenphysiol. 98: 459-464.

König J. and Peveling E. 1984. Cell walls of the phycobionts Trebouxia and Pseudotrebouxia: constituents and their localisation. Lichenology 16: 129-144.
Kozubek A. and Tyman J.H.P. 1999. Resorcinolic lipids, the natural non-isoprenic amphiphiles and their biological activity. Chem. Rev. 99: 1-26.

Kuypers M.M.M., Blokker P., Hopmans E.C., Kinkel H., Pancost R.D., Schouten S. and Sinninghe Damsté J.S. 2002. Archaeal remains dominate marine organic matter from the early Albian oceanic anoxic event $1 \mathrm{~b}$. Palaeogeogr. Palaeoclimatol. Palaeoecol. 185: 211-234.

Leppig U. and Montenari M. 2000. Organic-walled microfossils of possible dinoflagellate affinity from the Lower Permian of Sonora (northwest Mexico). Mar. Micropaleontol. 40: 1-8.

Lewis J., Harris A.S.D., Jones K.J. and Edmonds R.L. 1999. Long-term survival of marine planktonic diatoms and dinoflagellates in stored sediment samples. J. Plankton Res. 21: $343-354$.

Lille Ü. 2003. Current knowledge on the origin and structure of Estonian Kukersite kerogen. Oil Shale 20: 253-263.

Marchant H.J. 1977. Cell division and colony formation in the green alga Coelastrum (Chlorococcales). J. Phycol. 13: 102 110 .

Marret F. 1993. Les effets de l'acétolyse sur les assemblages des kystes de dinoflagellés. Palynoscience 2: 267-272.

McKinney D.E., Bortiatynski J.M., Carson D.M., Clifford D.J., de Leeuw J.W. and Hatcher P.G. 1996. Tetramethylammonium hydroxide (TMAH) thermochemolysis of the aliphatic biopolymer cutan: insights into the chemical structure. Org. Geochem. 24: 641-650.

Metzger P. and Largeau C. 1994. A new type of ether lipid comprising phenolic moieties in Botryococcus braunii. Chemical structure and abundance, and geochemical implications. Org. Geochem. 22: 801-814.

Metzger P. and Largeau C. 2002. Natural polyacetals. In: Matsumura S. and Steinbüchel A. (eds.), Miscellaneous Biopolymers and Biodegradation of Synthetic Polymers, Wiley-VCH, Weinheim, pp. 113-127.

Moldowan J.M., Dahl J., Jacobson S.R., Huizinga B.J., Fago F.J., Shetty R., Watt D.S. and Peters K.E. 1996. Chemostratigraphic reconstruction of biofacies: molecular evidence linking cyst-forming dinoflagellates with pre-Triassic ancestors. Geology 24: 159-162.

Montsant A., Zarka A. and Boussiba S. 2001. Presence of a nonhydrolysable biopolymer in the cell wall of vegetative cells and astaxanthin-rich cysts of Haematococcus pluvialis (Chlorophyceae). Mar. Biotechnol. 3: 515-521.

Morrill L.C. and Loeblich A.R. III 1981. The dinoflagellate pellicular wall layer and its occurrence in the division Pyrrophyta. J. Phycol. 17: 315-323.

van Mourik A. 2000. Chemical characterization of fossil palynomorphs; gonyaulacoid, peridinioid dinoflagellate cysts and sporomorphs. Masters Thesis Department of Geochemistry, Utrecht University, 49 pp.

Mösle B., Finch P., Collinson M.E. and Scott A.C. 1997. Comparison of modern and fossil plant cuticles by selective chemical extraction monitored by flash pyrolysis-gas chromatography-mass spectroscopy and electron microscopy. J. Anal. Appl. Pyrolysis 40-41: 585-597.

Mulder M.M., van der Hage E.R.E. and Boon J.J. 1992. Analytical in source pyrolytic methylation electron impact mass spectrometry of phenolic acids in biological matrices. Phytochem. Anal. 3: 165-172. 
Müller P.J., Kirst G., Ruhland G., Von Storch I. and Rosell-Melé A. 1998. Calibration of the alkenone paleotemperature index based on coretops from the eastern South Atlantic and global ocean $\left(60^{\circ} \mathrm{N}-60^{\circ} \mathrm{S}\right)$. Geochim. Cosmochim. Acta 62: $1757-1772$.

Porcella R.A. and Walne P.L. 1980. Microarchitecture and envelope development in Dysmorphococcus globosus (Phacotaceae, Chlorophyceae). J. Phycol. 16: 280-290.

Puel F., Largeau C. and Giraud G. 1987. Occurrence of a resistant biopolymer in the outer walls of the parasitic alga Prototheca wickerhamii (Chlorococcales): ultrastructure and chemical studies. J. Phycol. 23: 649-656.

Rascio N., Casadoro G. and Andreoli C. 1979. Ultrastructural features of Chlorella nana sp. nov. Bot. Mar. 22: 223-227.

Rodríguez M.C. and Cerezo A.S. 1996. The resistant 'biopolymer' in cell walls of Coelastrum sphaericum. Phytochemistry 43: $731-734$.

Rodríguez M.C., Noseda M.D. and Cerezo A.S. 1999. The fibrillar polysaccharides and their linkage to algaenan in the trilaminar layer of the cell wall of Coelastrum sphaericum (Chlorophyceae). J. Phycol. 35: 1025-1031.

Rozema J., Broekman R.A., Blokker P., Meijkamp B.B., de Bakker N., van de Staaij J., van Beem A., Ariese F. and Kars S.M. 2001. UV-B absorbance and UV-B absorbing compounds (para-cumaric acid) in pollen and sporopollenin: the perspective to track historic UV-B levels. J. Photochem. Photobiol. 62: 108-117.

Rozema J., van Geel B., Björn L.O., Lean J. and Madronich S. 2002. Toward solving the UV puzzle. Science 296: 1621-1622.

Rullkötter J. 1993. The thermal alteration of kerogen and the formation of oil. In: Engel M.H. and Macko S.A. (eds.), Organic Geochemistry. Principles and Applications, Plenum Press, New York, pp. 377-96.

Sarjeant W.A. 1978. Arpylorus antiquus Calandra, emend., a dinoflagellate cyst from the Upper Silurian. Palynol. 2: $167-179$.

Schenck P.A., de Leeuw J.W., van Graas G., Haverkamp J. and Bouman M. 1981. Analysis of recent spores and pollen and of thermally altered sporopollenin by flash pyrolysis-mass spectrometry and flash pyrolysis-gas chromatography-mass spectrometry. In: Brooks J. (ed.)Organic Maturation Studies and Fossil Fuel Exploration, Academic Press, London, pp. 225-237.

Schouten S., Hopmans E.C., Schefuss E. and Sinninghe Damsté J.S. 2002. Distributional variations in marine crenarchaeotal membrane lipids: a new tool for reconstructing ancient sea water temperatures? Earth Planet. Sci. Lett. 204: 265-274.

Schrank E. 1988. Effects of chemical processing on the preservation of peridinioid dinoflagellates: a case from the late cretaceous of NE Africa. Rev. Palaeobot. Palynol. 56: $123-$ 140.

Shaw G. 1971. The chemistry of sporopollenin. In: Brooks J. (ed.), Sporopollenin, Academic Press, London, pp. 305-350.

Simpson A.J., Zang X., Kramer R. and Hatcher P.G. 2003. New insights on the structure of algaenan from Botryococcus braunii race $\mathrm{A}$ and its hexane insoluble botryals based on multidimensional NMR spectroscopy and electrospray-mass spectrometry techniques. Phytochem. 62: 783-796.

Sinninghe Damsté J.S., Delas Heras F.X.C., de Bergen P.F. and de Leeuw J.W. 1993. Characterization of tertiary catalan lacustrine oil shales: discovery of extremely organic sulphur- rich Type I kerogens. Geochim. Cosmochim. Acta 57: $389-$ 415.

Srivastava A. and Prasad R. 2000. Triglycerides-based diesel fuels. Renew. Sust. Energ. Rev. 4: 111-133.

Staehelin L.A. and Picket-Heaps J.D. 1975. The ultrastructure of Scenedesmus (Chlorophyceae). I. Species with the 'reticulate' or 'warty' type of ornamental layer. J. Phycol. 11: 163-185.

Stankiewicz B.A., Briggs D.E.G., Michels R., Collinson M.E., Flannery M.B. and Evershed R.P. 2000. Alternative origin of aliphatic polymer kerogen. Geology 28: 559-562.

Strother P.K. 1996. Acritarchs. In: Jansonius J. and McGregor D.C. (eds.), Palynology: principles and applications, AASP Foundation, Salt Lake City, pp. 81-106.

Swift E. and Remsen C.C. 1970. The cell wall of Pyrocystis spp. (Dinophyceae). J. Phycol. 6: 79-86.

Syrett P.J. and Thomas E.M. 1973. The assay of nitrate reductase in whole cells of Chlorella: strain differences and the effect of cell walls. New Phytol. 72: 1307-1310.

Talyzina N.M., Moldowan J.M., Johannisson A. and Fago F.J. 2000. Affinities of Early Cambrian acritarchs studied by using microscopy, fluorescence flow cytometry and biomarkers. Rev. Palaeobot. Palynol. 108: 37-53.

Tegelaar E.W., de Leeuw J.W., Derenne S. and Largeau C. 1989. A reappraisal of kerogen formation. Geochim. Cosmochim. Acta 53: 3103-3106.

Tegelaar E.W., Kerp H., Visscher H., Schenck P.A. and de Leeuw J.W. 1991. Bias of the paleobotanical record as a consequence of variations in the chemical composition of higher vascular plant cuticles. Paleobiology 17: 133-144.

Tiffany L.H. 1924. A physiological study of growth and reproduction among certain algae. Ohio J. Sci. 24: 65-99.

Turon J.-L. 1984. Le palynoplancton dans l'environnement actuel de l'Atlantique nord-oriental. Évolution climatique et hydrologique depuis le dernier maximum glaciaire. Mem. Inst. Geol. Bassin Aquitaine 17: 1-313.

Versteegh G.J.M., Blokker P., Wood G., Collinson M.E., Sinninghe Damsté J.S. and de Leeuw J.W. 2004. Oxidative polymerization of unsaturated fatty acids as a preservation pathway for microalgal organic matter. Org. Geochem. 35: $1129-1139$

Versteegh G.J.M., Jansen J.H.F., de Leeuw J.W. and Schneider R.R. 2000. Mid-chain diols and keto-ols in sediments. A new tool for tracing past sea surface water masses? Geochim. Cosmochim. Acta 64: 1879-1892.

Versteegh G.J.M. and Zonneveld K.A.F. 2002. Use of selective degradation to separate preservation from productivity. Geology 30: 615-618.

Warnaar J. 2001. Chemical characterization of fossil organic walled dinoflagellate cysts. Masters Thesis, Department of Geochemistry, Utrecht University. 26 pp.

Wehling K., Niester C., Boon J.J., Willemse M.T.M. and Wiermann R. 1989. p-Coumaric acid - a monomer in the sporopollenin skeleton. Planta 179: 376-380.

Wicander R., Foster C.B. and Reed J.D. 1996. Green and bluegreen algae. Gloeocapsomorpha. In: Jansonius J. and McGregor D.C. (eds.), Palynology: Principles and Applications, AASP Foundation, Salt Lake City, pp. 215-225.

Wurdack M.E. 1923. Chemical composition of the walls of certain algae. Ohio J. Sci. 23: 181-191.

Yule B.L., Roberts S. and Marchall J.E.A. 2000. The thermal evolution of sporopollenin. Org. Geochem. 31: 859-870. 
Zárský V., Kalina T. and Sulek J. 1985. Notes on the sexual reproduction of Chlamydomonas geitleri Ettl. Arch. Protistenk. 130: $343-353$.

Zelibor J.L. Jr, Romankiw L., Hatcher P.G. and Colwell R.R. 1988. Comparitive analysis of the chemical composition of mixed and pure cultures of green algae and their decomposed residues by ${ }^{13} \mathrm{C}$ nuclear magnetic resonance spectroscopy. Appl. Env. Microbiol. 54: 1051-1060.

Zhang E., Hatcher P.G. and Davis A. 1993. Chemical composition of pseudo-phlobaphinite precursors: implications for the presence of aliphatic biopolymers in vitrinite from coal. Org. Geochem. 20: 721-734.

Zonneveld K.A.F., Versteegh G.J.M., de Lange and G. J. 1997. Preservation of organic walled dinoflagellate cysts in different oxygen regimes: a 10,000 years natural experiment. Mar. Micropaleontol. 29: 393-405.

Zonneveld K.A.F., Versteegh G.J.M. and de Lange G.J. 2001. Palaeoproductivity and post-depositional aerobic organic matter decay reflected by dinoflagellate cyst assemblages of the Eastern Mediterranean S1 sapropel. Mar. Geol. 172: 181-195. 